\title{
Quercetin and a plant substance, identified using a multi-copy number of DNA topoisomerase $I$ in recombinant Pichia pastoris, inhibited MDA-MB-231 proliferation via different manners.
}

\author{
Zhao Gang \\ The First Hospital of Jilin University \\ Chao Sin Pei \\ Universiti Sains Malaysia \\ Nur Adila Fadzil \\ Universiti Sains Malaysia \\ Lim Shern Kwok \\ Universiti Sains Malaysia
}

Chew Ai Lan

Universiti Sains Malaysia

Boon Yin Khoo ( $\boldsymbol{V}$ boonyin@usm.my )

Institute For Research In Molecular Medicine (INFORMM) https://orcid.org/0000-0003-1915-6606

\section{Research Article}

Keywords: Gene copy number, enzyme activity, DNA topoisomerase I, Pichia pastoris, potential anticancer agent screening, growth inhibitory effect, cell cycle, apoptosis, CYP gene expression

Posted Date: April 30th, 2021

DOI: https://doi.org/10.21203/rs.3.rs-341312/v2

License: (c) (i) This work is licensed under a Creative Commons Attribution 4.0 International License. Read Full License 


\section{Abstract}

The study employed an in vivo strategy to construct a multi-copy number of human DNA topoisomerase I (hTopl) gene using pPIC3.5K vector in GS115 strain of Pichia. The yeast transformant (GS115-pPIC3.5K$\mathrm{hTopl}$; clone) was then used to investigate the preliminary growth effect of a pure compound (quercetin) and a standardised subfraction of ethanolic red onion peel extract (F1). The clones' cell density was likely to be unaffected; only the total protein expression and enzyme activity were increased following the increased copy number of hTop1 in the host. The clone that showed the target enzyme's highest activity is said to respond specifically to growth inhibitors, whereby both quercetin and F1 were proven to be potential growth inhibitors as assessed by the MTT assay. In the process, quercetin reduced cell proliferation by inducing apoptosis and cell cycle arrest (S phase only), whereas $\mathrm{F} 1$ reduced cell proliferation by inducing cell cycle arrest only ( $S$ and $\mathrm{G} 2$ phases). Quercetin and F1 induced CYP1A1 and CYP1B1 (carcinogenicity) gene mRNA expression, but only F1 induced CYP2S1 (cytotoxicity) gene mRNA expression in the treated cells, suggesting that both quercetin and F1 inhibited the cell proliferation of MDA-MB-231 via different manners. The newly developed GS115-pPIC3.5K-hTopl can be used to select various potential substances for breast cancer treatment in the future.

\section{Introduction}

DNA topoisomerases play important roles in cellular processes by regulating the topological state of DNA [1]. The inhibition of DNA topoisomerase activities is a successful approach in screening anticancer agents, in which agents that react to the enzymes are predicted to inhibit the growth of cancer cells. Therefore, the enzymes can be exploited as scientific and clinical tools to rapidly screen new inhibitors in vitro as anticancer agents [2-5]. The expression of DNA topoisomerases has been previously demonstrated in a few works [6-8]. However, the use of multi-copy number gene strategies to express a large yield of specific enzymes, e.g., human DNA topoisomerase I (hTopl), which is said to increase the host's sensitivity towards growth inhibitors, has never been demonstrated previously. In many cases, expression using single-copy gene transformants has been disappointingly low. A multi-copy number of gene expression strategy that produces tandem inserts of a gene by ligation (in vitro strategy) has been utilised, which was shown to be one of the most effective strategies to increase gene expression [9], whereas a more popular in vivo strategy, which utilises hyper-resistance to an antibiotic that allows users to screen the multi-copy inserts, conferring resistance to the antibiotic Geneticin, has not yet been used to express hTopl.

More than 500 recombinant proteins have been successfully expressed using Pichia pastoris [9], where Pichia is a faster and cheaper eukaryotic expression system than baculovirus or mammalian tissue culture [10]. The increasing popularity of the Pichia expression system is due to a few factors, including the availability of different strains commercially that can be used as expression systems, the simplicity of the techniques needed for molecular genetic manipulation and the similarity to those of $S$. cerevisiae. Second, Pichia can produce foreign proteins at high levels, both intracellularly and extracellularly. It can perform many eukaryotic post-translational modifications while being as easy to manipulate as $E$. coli 
and S. cerevisiae [11]. Taken together, the tightly regulated alcohol oxidase I promoter [12] and robust respiratory growth of this system that facilitates high cell densities [13-15] are also factors contributing to the rapid acceptance of this system over other expression systems. The preliminary screening of anticancer agents using cell-based assays is not encouraging because the assays are costly and require specific equipment, expertise, and specialised facilities. Therefore, it is better to have other alternatives to the screening process rather than relying on expensive and commercially available cell-based assays alone [16]; only candidate compounds that exhibit a positive effect at the early discovery stages will then proceed to the next drug discovery steps, to faster the preliminary screening process. In this study, a multicopy number of the hTopl gene was produced using the PPIC3.5K vector in the GS115 strain of Pichia to enhance the protein yield of interest in the host. It is hypothesised that the transformation of Pichia with multi-copy number genes may increase the target enzyme expression in the host to increase the sensitivity of the host to the testing compounds during the screening process.

This study also aimed to investigate the effects of the multi-copy number of hTopl in Pichia (multi-copy insert transformants) on its cell density, total protein expression, and enzyme activity. The multi-copy insert transformants were then used to a preliminary screen of the growth inhibitory effect of quercetin (main flavonoid of red onion peel ethanolic extract) and a red onion peel ethanolic extract subfraction (F1). The F1, which was produced in-house, contains high quercetin levels that can be considered a potential anticancer. Numerous epidemiological studies have revealed that dietary intake of onion reduces the risk of developing breast cancer [17-18]. A large number of in vitro and in vivo studies have also been conducted to confirm the anticancer properties of red onion peels. However, the cellular mechanism and cell metabolism induced by F1 has not been studied in detail. The cytotoxic effect of both pure and plant substances was further confirmed in breast cancer using MDA-MB-231. This study also investigated the cell cycle profile, apoptosis induction and mRNA expression of CYP genes in quercetin- and F1-treated MDA-MB-231. The findings will facilitate multi-copy insert yeast transformants to discover more viable therapeutic agents for breast cancer treatment from natural products with bioavailable, safe, cost-effective and minimal side effect properties in the future.

\section{Materials And Methods}

\section{Production of a multi-copy number insert in Pichia by an in vivo strategy}

Pichia, which had a multi-copy number of hTopl (target gene; insert), was first produced via an in vivo strategy. Each copy of hTopI was carried by pPIC3.5K plasmid (9.0 kb; Invitrogen, Carlsbad, USA). In the process, the complete nucleotide sequence encoded hTopl that had been generated in a previous study [19] was excised from a pPICZa-A-hTopI plasmid with the restriction endonucleases EcoRI (Thermo Fisher Scientific, Waltham, USA) and Notl (Thermo Fisher Scientific, Waltham, USA) in two separate enzymatic reactions. The sequence was then inserted into the pPIC3.5K plasmid at the EcoRI and Notl sites. The successful construction of the recombinant plasmid was then viewed by agarose gel electrophoresis and confirmed by sequencing. The extracted recombinant pPIC3.5K-hTopl plasmid was then linearised by digestion with restriction endonuclease Sal (Thermo Fisher Scientific, Waltham, USA) prior to 
transformation into Pichia strain GS115. The yeast transformants were then screened on agar plates containing various concentrations of Geneticin ${ }^{\circledR}$ (Invitrogen, Carlsbad, USA). The transformants that survived at a higher concentration of Geneticin ${ }^{\circledR}$ are said to have more copies of recombinant plasmids transferred into yeast cells. The yeast colonies were subjected to copy number insert screening as follows. A brief schematic of the overall construction is shown in Fig. 1.

\section{Screening the multi-copy number insert Pichia transformants}

A $200 \mu \mathrm{l}$ aliquot of sterile yeast extract peptone dextrose (YPD; Merck, Darmstadt, Germany) broth was added to each well of a microtiter plate using the aseptic technique. Each well of the first microtiter plate was inoculated with a single colony of the selected transformant (from the above section) using sterile toothpicks to resuspend the cells. The cell suspension in the microtiter plate was incubated at $30^{\circ} \mathrm{C}$ without shaking. After 2 days, $10 \mu \mathrm{l}$ of each culture was added to $190 \mu \mathrm{l}$ sterile YPD broth in a new microtiter plate with the orientation marked as the first microtiter plate to keep track of the wells. The microtiter plate was incubated again as above. The process was repeated using the third microtiter plate to adjust the culture to be approximately similar visually to ensure equivalent numbers of cells were spotted on Geneticin ${ }^{\circledR}$ contained YPD plates. After overnight incubation, $10 \mu \mathrm{l}$ of cell suspension from each well of the third microtiter plate was spotted on YPD plates containing 0 (control), $0.25,0.50,0.75$, and $1.00 \mathrm{mg} / \mathrm{ml}$ Geneticin ${ }^{\circledR}$ (Invitrogen, Carlsbad, USA). The cells were spotted on the agar in a regular pattern with a grid underneath the plate to ensure that an equal intensity of cells was spotted on the grid. The liquid of the cell suspension was allowed to soak in the gel, and then the plates were incubated at $30^{\circ} \mathrm{C}$ for 2-5 days to allow the colonies of Geneticin-resistant transformants to grow on the respective plates in the grid. Single colonies that could survive at different concentrations of Geneticin ${ }^{\circledR}$ were picked and re-streaking the selected colonies on respective Geneticin ${ }^{\circledR}$ contained YPD plates.

\section{Growth induction of the multi-copy number insert Pichia transformants}

A single antibiotic-resistant colony of Pichia transformants (GS115-pPIC3.5K-hTopl) from each Geneticin ${ }^{\circledR}$ contained YPD plate (as above) was inoculated in $5 \mathrm{ml}$ YPD medium. The cells were grown at $30^{\circ} \mathrm{C}$ overnight with shaking at $200 \mathrm{rpm}$. In a $1 \mathrm{~L}$ flask, $250 \mathrm{ml}$ fresh buffered glycerol complex medium (BMGY; Merck, Darmstadt, Germany) was inoculated with $250 \mu \mathrm{l}$ of the overnight culture. The culture was grown again overnight until the optical density (OD) at $600 \mathrm{~nm}$ reached 2.0. The culture was harvested by centrifugation at $3,000 \times \mathrm{g}$ for $5 \mathrm{~min}$ at room temperature. Removed the sample's supernatant, and the cell pellet was resuspended in $10 \mathrm{ml}$ buffered methanol-complex medium (BMMY; Merck, Darmstadt, Germany). The cell suspension was diluted with BMMY to a final volume of $25 \mathrm{ml}$ or until the culture reading at $600 \mathrm{~nm}$ reached 1.0 . The cells were induced with $0.5 \%$ methanol every $24 \mathrm{~h}$ at $30^{\circ} \mathrm{C}$ for $96 \mathrm{~h}$. The cells were collected every $12 \mathrm{~h}$ to measure the cell density that represented growth. The $\mathrm{OD}_{600}$ was adjusted to 2.0 at $0 \mathrm{~h}$ of cultivation. The cells were also collected on ice for protein sample preparation.

\section{Analysis of specific protein expression in the Pichia transformants by Western blotting}

For the cell pellets collected from each $\mathrm{ml}$ of sample on ice (as above), $100 \mu \mathrm{l}$ of breaking buffer and an equal volume of acid-washed glass beads were added. The mixture was vortexed for $30 \mathrm{sec}$ and then 
incubated for another $30 \mathrm{sec}$ at room temperature for a total of 10 cycles. The mixture was then centrifuged at maximum speed for $10 \mathrm{~min}$ at $4^{\circ} \mathrm{C}$. The clear supernatant was transferred to a fresh microcentrifuge tube for protein concentration analysis using the Protein Assay Kit (Bio-Rad Life Sciences, Hercules, USA) or stored at $-80^{\circ} \mathrm{C}$ until use. Twenty (20) $\mu \mathrm{g}$ of protein from each sample was then used for analysis by sodium dodecyl sulphate-polyacrylamide gel electrophoresis (SDS-PAGE). Following electrophoresis, the distributed proteins on the gel were transferred onto a nitrocellulose membrane (GE Healthcare, Munich, Germany) by the semidry transfer method using a Trans-blot SD Semidry Transfer Cell (Bio-Rad Life Sciences, Hercules, USA). After protein transfer, nonspecific proteins on the membrane were blocked with $5 \%$ blocking solution for $2 \mathrm{~h}$ on a shaker. Then washed the membrane with TBST 3 times for 10 min each. The membrane was incubated with purified mouse antihTopl (1:5,000 dilution in TBST; BD Pharmingen, San Jose, USA) at $4^{\circ} \mathrm{C}$ overnight. The next morning, the membrane was washed again with TBST as above. After washing, the membrane was incubated with horseradish peroxidase-conjugated goat anti-mouse IgG (1:10,000 dilution in TBST; BD Pharmingen, San Jose, USA) for $1 \mathrm{~h}$ on a shaker. The membrane was then washed again with TBST as above. The protein signal development process was carried out in the darkroom, whereby the membrane was first overlaid with chemiluminescence substrate (Thermo Fisher Scientific, Waltham, USA). Cling wrap was then overlaid on the wet membrane, followed by X-ray film (GE Healthcare, Munich, Germany) exposure for approximately $5 \mathrm{~min}$. The film was then immersed in developer solution (Sigma-Aldrich, Saint Louis, USA) for a few seconds, rinsed with tap water and then fixed with fixer solution (Sigma-Aldrich, Saint Louis, USA) for a few seconds. The developed film was then air-dried and photographed the signals on the X-ray film.

\section{Determination of recombinant enzyme activity by DNA relaxation assay}

The protein samples, as prepared above, were also used for enzyme activity determination by DNA relaxation assay. The assay was performed in a total volume of $20 \mu \mathrm{l}$ of reaction mixture containing $4 \mu \mathrm{l}$ of $5 \mathrm{X}$ hTopl reaction buffer, $1 \mu \mathrm{l}$ of $0.25 \mu \mathrm{g}$ pBR322 plasmid DNA, and $1 \mu \mathrm{l}$ of the protein sample [20]. Water was used instead of the protein sample in the reaction mixture for the negative control. All reactions were incubated at $37^{\circ} \mathrm{C}$ for $30 \mathrm{~min}$. Then, $4 \mu \mathrm{l}$ of $6 \mathrm{X} \mathrm{hTopl} \mathrm{stopping} \mathrm{buffer} \mathrm{was} \mathrm{added} \mathrm{to} \mathrm{the}$ reaction mixture to stop the reactions. The reaction mixture was then briefly centrifuged and electrophoresed on a 1\% (w/v) agarose gel in 0.5X TBE at $30 \mathrm{~V}$ for $200 \mathrm{~min}$. The gel was then stained with ethidium bromide for $30 \mathrm{~min}$ and destained by soaking it in distilled water for another $30 \mathrm{~min}$. The gel was viewed under ultraviolet (UV) light and photographed with an Alpha Innotech Fluorchem FC2 (Fisher Scientific, Edmonton, Canada). The enzyme action is expressed as $\mathrm{B} / \mathrm{A} \times 10^{6} \mathrm{UL}^{-1}$, whereby $\mathrm{A}$ is an appropriate volume of supernatant added to the reaction. In contrast, $B$ is the dilution factor of the supernatant required to complete the relaxation of $0.25 \mu \mathrm{g}$ of pBR322 plasmid DNA.

\section{Screening quercetin and $\mathrm{F} 1$ effects by yeast-based assay}

The Pichia transformants that exhibited the highest enzyme activity were retrieved with $5 \mathrm{ml}$ of BMGY. The inoculated $\mathrm{BMGY}$ was grown at $30^{\circ} \mathrm{C}$ with shaking at $250 \mathrm{rpm}$ for $18 \mathrm{~h}$. After overnight incubation, the transformants' cell density was adjusted by consecutive serial dilution with a dilution factor of 1:20. 
Approximately $5 \mu \mathrm{l}$ of the transformants with a dilution factor of $7.81 \times 10^{-10}$ was then spotted in triplicate on the microbiological agar plates of YPD that contained $0 \mu \mathrm{g} / \mathrm{ml}$ (control), $25 \mu \mathrm{g} / \mathrm{ml}, 50 \mu \mathrm{g} / \mathrm{ml}$, $75 \mu \mathrm{g} / \mathrm{ml}$ and $100 \mu \mathrm{g} / \mathrm{ml}$ quercetin (Cayman Chemical, Michigan, USA) or F1 [21]. The control contained $<1 \%$ of dimethyl sulfoxide (DMSO; Merck, Darmstadt, Germany). The cells were then spotted on the agar in a regular pattern with a grid underneath the plate to ensure the equal intensity of the cell spotting on the grid. The cell suspension liquid was allowed to soak in the gel, and the plates were incubated at $30^{\circ} \mathrm{C}$ for 3 days. Pictures of the colonies were taken consecutively for 3 days to observe the transformants' growth in the plates.

\section{Breast cancer cell culture, seeding and treatment}

The MDA-MB-231 (ATCC $® H T B-26^{\mathrm{TM}}$ ) cell line was purchased from the American Type Culture Collection (ATCC, Virginia, USA). The cells were cultured in the complete growth medium in T-25 or T-75 tissue culture flasks (Nunc, Rosilde, Denmark). The growth medium contained high glucose Dulbecco's Modified Eagle's Medium (Thermo Fisher Scientific Inc.) supplemented with 10\% (v/v) foetal bovine serum (FBS;

Thermo Fisher Scientific Inc.), 100 units $/ \mathrm{ml}$ penicillin and $100 \mu \mathrm{g} / \mathrm{ml}$ streptomycin. The MDA-MB-231 was incubated at $37^{\circ} \mathrm{C}$ in a humidified atmosphere of $5 \%(\mathrm{v} / \mathrm{v})$ carbon dioxide $\left(\mathrm{CO}_{2}\right)$ and grown with a doubling time of approximately $38 \mathrm{~h}$. The MDA-MB-231 was trypsinised, when the number of cells in the culture flasks had reached sufficient growth. The cells were seeded in 96-well plates at a cell density of 2 $\times 10^{4}$ cells $/ \mathrm{ml}$ for growth inhibitory effect analysis or in 6-well plates at a cell density of $1.2 \times 10^{6}$ cells/ml for cell cycle, apoptotic effect and CYP mRNA expression analyses. The cells were then subjected to treatment with $0.5 \%$ DMSO (control) or $60 \mu \mathrm{g} / \mathrm{ml}$ quercetin or $50 \mu \mathrm{g} / \mathrm{ml} \mathrm{F1}$ in growth media that contained only $2 \% \mathrm{FBS}$. The treated cells were incubated at $37^{\circ} \mathrm{C}$ in a $5 \%(\mathrm{v} / \mathrm{v}) \mathrm{CO}_{2}$ incubator for 24 , 48 and $72 \mathrm{~h}$ prior to further analysis.

\section{Growth inhibitory effect analysis of quercetin and F1 by MTT assay}

The cells treated with quercetin and F1 in 96-well plates, as described above, at the end of each incubation period, were added with $24 \mu \mathrm{l}$ of $5 \mathrm{mg} / \mathrm{ml}$ MTT reagent (Sigma-Aldrich, St. Louis, MO, USA) in each well. The reaction was incubated for $4 \mathrm{~h}$. Carefully removed the solution without disturbing the formazan crystals formed in each well. Next, $100 \mu \mathrm{l}$ acidified isopropanol (Sigma-Aldrich, St. Louis, MO, USA) was added to each well and agitated to promote homogeneous colour development. Following colour development, the colour's intensity in each well was read at $570 \mathrm{~nm}$ using an ELISA plate reader (Tecan, Männedorf, Switzerland).

\section{Cell cycle analysis of quercetin- and F1-treated MDA-MB-231 by flow cytometry}

The cells treated with quercetin and F1 in 6-well plates, as described above, were trypsinised at the end of each incubation period, and the cell suspension was transferred into falcon tubes. The cell suspension with the old medium in the tube was centrifuged at $1,000 \mathrm{~g}$ for $5 \mathrm{~min}$. The supernatant was then discarded, and the cell pellet was washed with PBS. After washing, a $1 \times 10^{6}$ cell suspension was transferred into new falcon tubes, and the cell suspension was then centrifuged as above. The cells were 
then fixed and permeabilised by adding $70 \%$ ice-cold absolute ethanol dropwise with gently mixing. The cell suspension was then stored at $4^{\circ} \mathrm{C}$ overnight to allow fixation. The ethanol-fixed cells were centrifuged at 1,000 $\mathrm{g}$ for $10 \mathrm{~min}$ and washed by resuspending the cells in PBS. The washed cells were then stained with $500 \mu \mathrm{FxCycle}{ }^{\mathrm{TM}}$ propidium iodide (PI)/RNAse Staining Solution (Thermo Fisher Scientific, Massachusetts. USA) in the dark for $30 \mathrm{~min}$. The stained samples were transferred into new sterile flow tubes and kept on ice until subjected to flow cytometry analysis using a BD FACSCalibur (BD Biosciences, New Jersey, USA). Analysed cell cycle distribution from a total of 15,000 events with Cell Quest software 3.3 (BD Biosciences, New Jersey, USA). The percentage of cells in each phase was analysed and plotted as a DNA histogram using ModFit LT ${ }^{\mathrm{TM}}$ software (BD Biosciences, New Jersey, USA). The entire analysis was performed at the Advanced Medical and Dental Institute (AMDI), USM in Bertam, Penang.

\section{Apoptotic effect analysis of quercetin- and F1-treated MDA-MB-231 by flow cytometry}

The cells treated with quercetin and F1 in 6-well plates, as described above, were also subjected to apoptotic effect analysis using the Annexin V-FITC Apoptosis Detection Kit (Thermo Fisher Scientific, Massachusetts. USA). Briefly, the trypsinised cells collected in $15 \mathrm{ml}$ falcon tubes were centrifuged at 400 $\mathrm{g}$ for $4 \mathrm{~min}$ at $4^{\circ} \mathrm{C}$ to remove the old medium. Then, the cells were washed twice with $3 \mathrm{ml}$ of cold PBS. The cell suspension was counted, and $5 \times 10^{5} \mathrm{cells} / \mathrm{ml}$ was transferred into new falcon tubes. The cells were centrifuged to remove the supernatant, and then the cell pellet was resuspended in $200 \mu \mathrm{l}$ of $1 \mathrm{X}$ binding buffer. A volume of $5 \mu \mathrm{l}$ Annexin V-FITC was then added to $195 \mu \mathrm{l}$ of the cell suspension, mixed well, and incubated in the dark at room temperature for $10 \mathrm{~min}$. The cells were then washed with $200 \mu \mathrm{l}$ of $1 \mathrm{X}$ binding buffer. The cells were resuspended in $190 \mu \mathrm{l}$ of $1 \mathrm{X}$ binding buffer prior to the addition of $10 \mu \mathrm{l}$ of PI $(20 \mu \mathrm{g} / \mathrm{ml})$. The mixture was transferred to a new sterile tube for flow cytometry analysis using a BD FACSCalibur (BD Biosciences, New Jersey, USA) with $488 \mathrm{~nm}$ excitation, 655-730 nm emission for PI, and $525 \mathrm{~nm}$ emission for FITC.

\section{CYP expression analysis in quercetin- and F1-treated MDA-MB-231 by real-time PCR}

The cells treated with quercetin and F1 in 6-well plates, as described above, were also subjected to total RNA extraction using the TRIzol Total RNA Isolation Reagent (Life Technologies Corporation, Carlsbad, CA, USA). The extracted total RNA pellet was then air-dried for $15 \mathrm{~min}$ and resuspended in $25 \mu \mathrm{l}$ RNasefree water. Only the extracted total RNA with an absorbance A260/A230 ratio within 1.8-2.0 and an

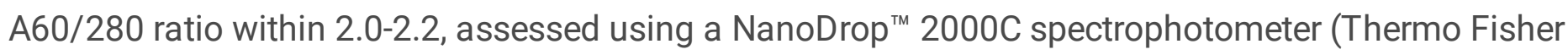
Scientific, USA), was used for cDNA conversion. The bands that indicated a good quality of RNA, assessed by $1 \%(\mathrm{w} / \mathrm{v})$ agarose gel electrophoresis, were visualised and captured under UV light by an image analyser (Syngene, Cambridge, UK). The extracted total RNA was then reverse transcribed to cDNA using a Tetro cDNA Synthesis Kit (Bioline, London, UK). Kept the reverse transcription products (CDNA) at $-20^{\circ} \mathrm{C}$ until the products were used for real-time PCR gene expression analysis. All primers were designed using Primer Express Software v3.0.1 (Thermo Fisher Scientific, Massachusetts. USA; Table 1). All oligonucleotide primers ordered from Integrated DNA Technologies (Coralville, USA) were packed in desalted lyophilised form. The primers' stocks were dissolved in RNase-free water (Sigma-Aldrich, St. 
Louis, USA) to generate a final $100 \mu \mathrm{M}$ concentration of each primer solution. The primer solutions were stored at $-20^{\circ} \mathrm{C}$ until use. Real-time PCR was performed using an Agilent AriaMx Real-Time PCR System (Agilent, California, USA). The PCR cocktail was prepared by adding $10 \mu \mathrm{ITaq}^{\mathrm{TM}}$ Universal SYBR Green Supermix (Bio-Rad, California, USA), $0.8 \mu$ of $10 \mu \mathrm{M}$ forward and reverse primer each for the gene of interest (GOI) and $50 \mathrm{ng}$ CDNA diluted in nuclease-free water to a total volume of $20 \mu \mathrm{l}$ in each well of 0.1 $\mathrm{ml}$, 8-tube qPCR strips (AITbiotech, Singapore). The reactions were initiated with a hot start at $95^{\circ} \mathrm{C}$ for 30 sec, followed by 40 cycles of amplification at $95^{\circ} \mathrm{C}$ for $15 \mathrm{sec}$ as the denaturation step and $60^{\circ} \mathrm{C}$ for $1 \mathrm{~min}$ as the annealing and extension step. The reactions were continued at 1 cycle of thermal profile consisting of $95^{\circ} \mathrm{C}$ for $15 \mathrm{sec}$, followed by $60^{\circ} \mathrm{C}$ for $1 \mathrm{~min}, 95^{\circ} \mathrm{C}$ for $30 \mathrm{sec}$ and $60^{\circ} \mathrm{C}$ for $15 \mathrm{sec}$ to generate a melting curve. The expression value of $\mathrm{GOI}$ was normalised to glyceraldehyde-3-phosphate dehydrogenase (GAPDH), whereby the relation between the normalised GOI in treated and vehicle control samples was determined by the fold change using the following formula: $2^{\wedge}(-\Delta \Delta C t)$ [22]. The fold change value for the vehicle control was set as 1 , whereas an expression change value $>1$ represented upregulation and that of $<1$ represented downregulation of the gene.

Table 1

The list of primers used for real-time PCR.

\begin{tabular}{|c|c|c|}
\hline Gene & Primer Sequence & Size amplicon \\
\hline \multirow[t]{2}{*}{ CYP1A1 } & Forward 5'-TCAGGAGAAGCAGCTGGATGA-3' & \multirow[t]{2}{*}{$76 \mathrm{bp}$} \\
\hline & Reverse 5'-GAGGTCCAAGACGATGTTAATGATC-3' & \\
\hline \multirow[t]{2}{*}{ CYP1B1 } & Forward 5'-ATCAGGTGAGGTGTGCTCCAT-3' & \multirow[t]{2}{*}{$70 \mathrm{bp}$} \\
\hline & Reverse 5'-TCTCCCAGAAGCTCCTGCATA-3' & \\
\hline \multirow[t]{2}{*}{ CYP2S1 } & Forward 5'-GACAGGGTTAATGTCTCCAGAGTGT-3' & \multirow[t]{2}{*}{$78 \mathrm{bp}$} \\
\hline & Reverse 5'-GGACAGACTCCGGAAAACAACT-3' & \\
\hline \multirow[t]{2}{*}{ GAPDH } & Forward 5'-ACAGCCTCAAGATCATCAGCA-3' & \multirow[t]{2}{*}{$137 \mathrm{bp}$} \\
\hline & Reverse 5'AGTCTTCTGGGTGGCAGTGAT-3' & \\
\hline
\end{tabular}

\section{Statistical analysis}

The dose-response growth curves were generated using GraphPad Prism version 8.2.1 for Windows (GraphPad Software Inc., La Jolla, CA, USA). The statistical analysis was presented as the mean \pm SD of triplicate determinations. The Student's $t$-test was used to analyse the cell density, total protein expression and enzyme activity to compare mean values between 2 datasets. In contrast, one-way analysis of variance (ANOVA) was used to analyse the mRNA gene expression with an additional Dunnett's multiple comparisons test to compare 2 among 3 or more datasets. Data analysis was also performed for photographs using ImageJ scientific software. The level of significance was set at $a=0.05$ (95\% 
confidence interval), where the confidence levels were indicated as statistically significant by asterisks * for $p$-values $<0.05$, ** for $p$-values $<0.01$ and $* \star \star$ for $p$-values $<0.001$.

\section{Results}

\section{The constructed recombinant plasmid for in vivo strategy yeast transformation}

Figure 2 shows a single copy of the hTopl fragment ( 2,717 bp) that was ligated into the pPIC3.5K plasmid ( 8,575 bp) at the EcoRI and Notl sites, producing the pPIC3.5K plasmid containing a single copy of hTopl (pPIC3.5K-hTopl). The recombinant pPIC3.5K-hTopl plasmid, which was expected to be 11,292 bp in length, was then linearised with the Sall prior to the transformation Pichia via an in vivo strategy to determine the effect of gene copy number on cell growth and total protein expression in the yeast transformants. The pPIC3.5K-hTopl plasmid was digested with EcoRI and Notl to confirm that all extracted plasmids harboured the correct insert. The extracted plasmid DNAs were also sent for sequencing to verify that each plasmid's correct insert was cloned. The nucleotide sequence (Submission \# 2391932) of the insert in the plasmid is shown in Fig. 3. The results indicated that the recombinant pPIC3.5K-hTopl plasmid was successfully constructed.

\section{In vivo screening of multi-copy insert transformants}

The multi-copy inserts of His + transformants were produced post linearised pPIC3.5K-hTopl plasmid DNA was transformed into the Pichia strain of GS115. As many as 68 yeast transformants (GS115-pPIC3.5KhTopl) were selected for subculturing from the microtiter plate. From our observations, clones 46, 35, 19 and 50 were selected from the plates that contained $0.25,0.50,0.75$, and $1.00 \mathrm{mg} / \mathrm{ml}$ Geneticin, respectively (Fig. 4A-D). The selection was based on the clones' ability to survive on agar plates containing various antibiotic concentrations. The Pichia transformants (GS115-pPIC3.5K-hTopl), which were successfully constructed via an in vivo strategy and resistant to various Geneticin concentrations, were subjected later to cell growth (density) and total protein expression analyses.

\section{Cell growth and total protein expression of the transformants}

Figure $5 \mathrm{~A}$ shows the cell density of the collected cultures every $12 \mathrm{~h}$, whereby the cell density increased with the incubation times. The highest cell density was observed in the GS115-pPIC3.5K-hTopl resistant to $0.50 \mathrm{mg} / \mathrm{ml}$ Geneticin at $96 \mathrm{~h}$ of incubation. The absorbance of the cell density of the His + transformants at this time point was 11.39 units at $\mathrm{OD}_{600}$. However, increasing the number of inserts and incubation time did not increase the transformants' cell density. The transformants resistant to 0.25 $\mathrm{mg} / \mathrm{ml}$ Geneticin at 60 and $84 \mathrm{~h}$ of incubation times showed similar cell densities: 11.19 units and 11.33 units at $\mathrm{OD}_{600}$, respectively. Similarly, the increase in insert copy number and incubation time did not increase the expression level of total protein in the transformants. In brief, the highest total protein expression was obtained in the clone that was resistant to $1.00 \mathrm{mg} / \mathrm{ml}$ Geneticin at $48 \mathrm{~h}$ of incubation and $0.75 \mathrm{mg} / \mathrm{ml}$ Geneticin at $60 \mathrm{~h}$ of incubation (Fig. 5B). The expression levels of these transformants' total protein were 1.76 and $1.75 \mathrm{mg} / \mathrm{ml}$, respectively. Other GS115-pPIC3.5K-hTopl strains that showed similar total protein expression levels were also observed in the transformants resistant to $1.00 \mathrm{mg} / \mathrm{ml}$ 
Geneticin at $24 \mathrm{~h}$ of incubation $(1.70 \mathrm{mg} / \mathrm{ml})$ and $1.00 \mathrm{mg} / \mathrm{ml}$ Geneticin at $84 \mathrm{~h}$ of incubation $(1.72$ $\mathrm{mg} / \mathrm{ml}$ ). In summary, the level of total protein expression in the clones of GS115-pPIC3.5K-hTopl, which were resistant to various concentrations of Geneticin, showed the GS115-pPIC3.5K-hTopl that showed the highest level of total protein expression and resistance to $0.25 \mathrm{mg} / \mathrm{ml}$ Geneticin was the clone collected at $24 \mathrm{~h}$ of incubation $(1.60 \mathrm{mg} / \mathrm{ml})$. The GS115-pPIC3.5K-hTopl that showed the highest level of total protein expression and resistance to $0.50 \mathrm{mg} / \mathrm{ml}$ Geneticin was the clone collected at $36 \mathrm{~h}$ of incubation $(1.68 \mathrm{mg} / \mathrm{ml})$, the GS115-pPIC3.5K-hTopl that showed the highest level of total protein expression and resistance to $0.75 \mathrm{mg} / \mathrm{ml}$ Geneticin was the clone collected at $60 \mathrm{~h}$ of incubation and $(1.75 \mathrm{mg} / \mathrm{ml})$, and the GS115-pPIC3.5K-hTopl that showed the highest level of total protein expression and resistance to $1.00 \mathrm{mg} / \mathrm{ml}$ Geneticin was the clone collected at $48 \mathrm{~h}$ of incubation $(1.76 \mathrm{mg} / \mathrm{ml})($ Table 2$)$. These four clones were selected for comparison for subsequent experiments. Although the highest expression level of total protein was found in the selected transformants, normalisation of the increased total protein expression level in all transformants with cell density per se did not show any statistical significance. 
Table 2

Cell density and total protein expression by GS115-pPIC3.5K-hTopl were resistant to various Geneticin concentrations by spectrophotometry and Bio-Rad protein assays. All clones were cultured on antibiotic contained agar plates for $96 \mathrm{~h}$.

\begin{tabular}{|c|c|c|c|c|c|}
\hline $\begin{array}{l}\text { Time } \\
\text { Point } \\
\text { (hour) }\end{array}$ & $\begin{array}{l}\text { Geneticin }{ }^{\circledR} \\
\text { Concentration } \\
\text { (mg/ml) }\end{array}$ & $\begin{array}{l}\text { Cell Density } \\
\text { (Absorbance } \\
\left.\text { OD }_{600}\right)\end{array}$ & $\begin{array}{l}\text { Total } \\
\text { Protein } \\
(\mathrm{mg} / \mathrm{ml})\end{array}$ & $\begin{array}{l}\text { Total protein per } \\
\text { hour } \\
\text { (mg/ml/hour) }\end{array}$ & $\begin{array}{l}\text { Total Protein per } \\
\text { cell density } \\
\text { (mg/ml/unit) }\end{array}$ \\
\hline \multirow[t]{4}{*}{12} & $0.25 \mathrm{mg} / \mathrm{ml}$ & 7.38 & 1.02 & 0.08 & 0.14 \\
\hline & $0.50 \mathrm{mg} / \mathrm{ml}$ & 5.14 & 1.40 & 0.12 & 0.27 \\
\hline & $0.75 \mathrm{mg} / \mathrm{ml}$ & 8.33 & 0.69 & 0.06 & 0.08 \\
\hline & $1.00 \mathrm{mg} / \mathrm{ml}$ & 7.60 & 1.68 & 0.14 & 0.22 \\
\hline \multirow[t]{4}{*}{24} & $0.25 \mathrm{mg} / \mathrm{ml}$ & 7.75 & 1.60 & 0.07 & 0.21 \\
\hline & $0.50 \mathrm{mg} / \mathrm{ml}$ & 5.45 & 1.60 & 0.07 & 0.29 \\
\hline & $0.75 \mathrm{mg} / \mathrm{ml}$ & 8.15 & 1.35 & 0.06 & 0.17 \\
\hline & $1.00 \mathrm{mg} / \mathrm{ml}$ & 7.48 & $1.70 \#$ & 0.07 & 0.23 \\
\hline \multirow[t]{4}{*}{36} & $0.25 \mathrm{mg} / \mathrm{ml}$ & 9.09 & 1.15 & 0.03 & 0.13 \\
\hline & $0.50 \mathrm{mg} / \mathrm{ml}$ & 7.57 & 1.68 & 0.05 & 0.22 \\
\hline & $0.75 \mathrm{mg} / \mathrm{ml}$ & 9.72 & 1.52 & 0.04 & 0.16 \\
\hline & $1.00 \mathrm{mg} / \mathrm{ml}$ & 9.70 & 1.50 & 0.04 & 0.15 \\
\hline \multirow[t]{4}{*}{48} & $0.25 \mathrm{mg} / \mathrm{ml}$ & 8.65 & 0.99 & 0.02 & 0.11 \\
\hline & $0.50 \mathrm{mg} / \mathrm{ml}$ & 7.56 & 1.59 & 0.03 & 0.21 \\
\hline & $0.75 \mathrm{mg} / \mathrm{ml}$ & 9.49 & 1.39 & 0.03 & 0.15 \\
\hline & $1.00 \mathrm{mg} / \mathrm{ml}$ & 9.16 & $1.76^{\#}$ & 0.04 & 0.19 \\
\hline \multirow[t]{4}{*}{60} & $0.25 \mathrm{mg} / \mathrm{ml}$ & $11.19^{\#}$ & 0.86 & 0.01 & 0.08 \\
\hline & $0.50 \mathrm{mg} / \mathrm{ml}$ & 9.02 & 1.20 & 0.02 & 0.13 \\
\hline & $0.75 \mathrm{mg} / \mathrm{ml}$ & 10.69 & $1.75^{\#}$ & 0.03 & 0.16 \\
\hline & $1.00 \mathrm{mg} / \mathrm{ml}$ & 10.50 & 1.21 & 0.02 & 0.12 \\
\hline \multirow[t]{2}{*}{72} & $0.25 \mathrm{mg} / \mathrm{ml}$ & 10.72 & 1.04 & 0.01 & 0.10 \\
\hline & $0.50 \mathrm{mg} / \mathrm{ml}$ & 9.39 & 1.16 & 0.02 & 0.12 \\
\hline
\end{tabular}

" \# " High level of cell density and total protein expression in the cultures. " " Clones that were selected for subsequent experiments. 


\begin{tabular}{|c|c|c|c|c|c|}
\hline $\begin{array}{l}\text { Time } \\
\text { Point } \\
\text { (hour) }\end{array}$ & $\begin{array}{l}\text { Geneticin }^{\circledR} \\
\text { Concentration } \\
\text { (mg/ml) }\end{array}$ & $\begin{array}{l}\text { Cell Density } \\
\text { (Absorbance } \\
\text { OD }_{600} \text { ) }\end{array}$ & $\begin{array}{l}\text { Total } \\
\text { Protein } \\
(\mathrm{mg} / \mathrm{ml})\end{array}$ & $\begin{array}{l}\text { Total protein per } \\
\text { hour } \\
\text { (mg/ml/hour) }\end{array}$ & $\begin{array}{l}\text { Total Protein per } \\
\text { cell density } \\
\text { (mg/ml/unit) }\end{array}$ \\
\hline & $0.75 \mathrm{mg} / \mathrm{ml}$ & 9.44 & 1.53 & 0.02 & 0.16 \\
\hline & $1.00 \mathrm{mg} / \mathrm{ml}$ & 9.78 & 1.59 & 0.02 & 0.16 \\
\hline \multirow[t]{4}{*}{84} & $0.25 \mathrm{mg} / \mathrm{ml}$ & 11.33 \# & 0.82 & 0.01 & 0.07 \\
\hline & $0.50 \mathrm{mg} / \mathrm{ml}$ & 10.18 & 1.05 & 0.01 & 0.10 \\
\hline & $0.75 \mathrm{mg} / \mathrm{ml}$ & 10.23 & 1.11 & 0.01 & 0.11 \\
\hline & $1.00 \mathrm{mg} / \mathrm{ml}$ & 9.78 & $1.72 \#$ & 0.02 & 0.18 \\
\hline \multirow[t]{4}{*}{96} & $0.25 \mathrm{mg} / \mathrm{ml}$ & 10.93 & 1.48 & 0.02 & 0.14 \\
\hline & $0.50 \mathrm{mg} / \mathrm{ml}$ & 11.39 \# & 1.45 & 0.02 & 0.13 \\
\hline & $0.75 \mathrm{mg} / \mathrm{ml}$ & 9.59 & 1.57 & 0.02 & 0.16 \\
\hline & $1.00 \mathrm{mg} / \mathrm{ml}$ & 9.08 & 1.18 & 0.01 & 0.13 \\
\hline
\end{tabular}

Specific protein expression and enzyme activity of hTopl on selected clones

The expression analysis showed that a protein band of approximately $91 \mathrm{kDa}$ was observed in the total protein of all four selected clones (Fig. 6A). The $91 \mathrm{kDa}$ protein was detected by the antibody purified from mouse anti-human DNA Topl, indicating that the protein of interest was successfully expressed in the multi-copy gene of $\mathrm{His}^{+}$transformants using the in vivo strategy (Fig. 6B). The clones of GS115pPIC3.5K-hTopl resistant to $0.25 \mathrm{mg} / \mathrm{ml}$ Geneticin and were collected at $24 \mathrm{~h}$ of incubation, resistant to $0.50 \mathrm{mg} / \mathrm{ml}$ Geneticin and were collected at $36 \mathrm{~h}$ of incubation, resistant to $0.75 \mathrm{mg} / \mathrm{ml}$ Geneticin and were collected at $60 \mathrm{~h}$ of incubation, and resistant to $1.00 \mathrm{mg} / \mathrm{ml}$ Geneticin and were collected at $48 \mathrm{~h}$ of incubation, were then subjected to the determination of the activity of hTopl. The clones' hTopl activity was assayed based on the ability of hTopl to relax pBR322 supercoiled DNA. Figure 6C shows that hTopl expressed by GS115-pPIC3.5K-hTopl resistant to various Geneticin concentrations could successfully relax the pBR322 supercoiled DNA compared with the supercoiled DNA in the reaction without hTopl. The supercoiled DNA migrated faster than the relaxed form of DNA due to the smaller size of the DNA, and hence, the band of supercoiled DNA appeared lower than the relaxed form of the DNA on the same agarose gel. The enzyme activity of hTopl in GS115-pPIC3.5K-hTopl resistance to various Geneticin concentrations is also summarised in Table 3. The highest enzyme activity of hTopl was observed in the culture expressed by GS115-pPIC3.5K-hTopl resistant to $1.00 \mathrm{mg} / \mathrm{ml}$ Geneticin $\left(19.7 \times 10^{4} \mathrm{UL}^{-1} \mathrm{OD}_{600^{-1}}\right)$. The enzyme activity was approximately 3 times greater than the enzyme activity of hTopl in GS115- 
pPIC3.5K-hTopl resistant to $0.25 \mathrm{mg} / \mathrm{ml}$ Geneticin $\left(7.74 \times 10^{4} \mathrm{UL}^{-1} \mathrm{OD}_{600^{-1}}\right)$. The enzyme activities of hTopl in GS115-pPIC3.5K-hTopl resistant to 0.50 and $0.75 \mathrm{mg} / \mathrm{ml}$ Geneticin were $10.6 \times 10^{4} \mathrm{UL}^{-1} \mathrm{OD}_{600^{-1}}$ and $9.35 \times 10^{4} \mathrm{UL}^{-1} \mathrm{OD}_{600^{-1}}$, respectively. This phenomenon demonstrated that the enzyme activity of hTop1 produced in GS115-pPIC3.5K-hTopl was likely to be proportional to the level of antibiotic resistance or increased with the target gene's increment copy number in each clone.

Table 3

The activity of hTopl in the clones of GS115-pPIC3.5K-hTopl resistant to various Geneticin concentrations.

\begin{tabular}{|llll|}
\hline $\begin{array}{l}\text { Clone resistant to } \\
\text { Geneticin }\end{array}{ }^{\circledR}(\mathrm{mg} / \mathrm{ml})$ & $\begin{array}{l}\mathrm{OD}_{600} \text { of } \\
\text { culture }\end{array}$ & $\begin{array}{l}\text { Intracellular enzyme activity } \\
\left(\mathrm{UL}^{-1} \mathrm{OD}_{600^{-1}}\right)\end{array}$ & $\begin{array}{l}\text { Total enzyme } \\
\text { activity }\left(\mathrm{UL}^{-1}\right)\end{array}$ \\
\hline 0.25 & 7.75 & $7.74 \times 10^{4}$ & $3.02 \times 10^{6}$ \\
\hline 0.50 & 7.57 & $10.6 \times 10^{4}$ & $4.02 \times 10^{6}$ \\
\hline 0.75 & 10.69 & $9.35 \times 10^{4}$ & $5.02 \times 10^{6}$ \\
\hline 1.00 & 9.16 & $19.7 \times 10^{4}$ & $9.04 \times 10^{6}$ \\
\hline
\end{tabular}

\section{The activity of Pichia transformants for visual screening purposes}

Visual screening using microbiological agar plates containing various concentrations of quercetin or F1 showed a decrease in intensity (growth) of the Pichia transformants (GS115-pPIC3.5K-hTopl) that expressed the highest enzyme activity of hTopl and were resistant to $1.00 \mathrm{mg} / \mathrm{ml}$ Geneticin, after three days of incubation. The average intensities of the transformants after $7.81 \times 10^{-10}$ dilution on agar plates containing various quercetin concentrations showed no significant difference after three days of incubation (Fig. 7A). In contrast, the average intensity of the transformants at the same dilution on agar plates containing $25 \mu \mathrm{g} / \mathrm{ml} \mathrm{F1}$ were $145.01 \pm 0.45,141.12 \pm 0.42$, and $139.84 \pm 2.23(p<0.05)$ at day 1,2 , and 3 of incubation, respectively (Fig. 7B). Therefore, the yeast-based screening assays able to differentiate the growth inhibitory activity of quercetin and F1.

\section{Cytotoxic effects of quercetin- and F1-treated MDA-MB-231}

The ideal dose-response of quercetin was not observed on the cancer cells at $24 \mathrm{~h}$ of treatment (Fig. 8A). The ideal dose-response of quercetin was only observed on the cancer cells at 48 (hillslope=-2.247; maximal response $\leq 75 \%$ ) (Fig. $8 \mathrm{~B}$ ) and $72 \mathrm{~h}$ of treatment (hillslope $=-2.785$; maximal response $\leq 50 \%$ ) (Fig. 8C). The cytotoxic effect in MDA-MB-231 treated with F1 resulted in the ideal dose-response of the test compound on the cancer cells at 24 (hillslope=-0.49; maximal response $\leq 25 \%$ ) (Fig. 8D) and $48 \mathrm{~h}$ of treatment (hillslope=-0.76; maximal response $\leq 25 \%$ ) (Fig. 8E). However, the ideal dose-response of F1 on the cancer cells did not persist until $72 \mathrm{~h}$ of treatment (Fig. 8F). Although quercetin showed a good later 
growth inhibitory effect on the cancer cells following $72 \mathrm{~h}$ of treatment, $\mathrm{F} 1$ showed a good early growth inhibitory effect on MDA-MB-231. As for the half-maximal effective concentration (EC50) value, only MDA-MB-231 post F1 treatment for $48 \mathrm{~h}$ showed the EC50 value $\leq 50 \mu \mathrm{g} / \mathrm{ml}(10.22 \mu \mathrm{g} / \mathrm{ml})$; compounds that exhibited EC50 value $\geq 50 \mu \mathrm{g} / \mathrm{ml}$ are considered as inactive. The differences in growth inhibitory activity of quercetin and F1 could be predicted by the yeast-based screening assay and further confirmed using the MTT assay.

\section{Cell cycle profile of quercetin- and F1-treated MDA-MB-231}

The cell cycle profile of MDA-MB-231 treated with 0.5\% DMSO (control), $60 \mu \mathrm{g} / \mathrm{ml}$ quercetin, and 50 $\mu \mathrm{g} / \mathrm{ml} \mathrm{F1}$ for 24,48 , and $72 \mathrm{~h}$ showed changes in cell cycle phases. The distribution of cell cycle phases in MDA-MB-231 treated with quercetin for $24 \mathrm{~h}$ showed no significant difference compared to the controls (Fig. 9A). Conversely, the cell population in S phase for F1-treated cells increased significantly to $53.13 \%$ $(p<0.001)$, accompanied by a decrease in the cell population in $\mathrm{G} 0 / \mathrm{G} 1$ phase to $39.68 \%(p<0.001)$ compared to respective controls (DMSO-treated MDA-MB-231), but with no significant effect on the cell population in G2/M phase at $24 \mathrm{~h}$ of treatment. At $48 \mathrm{~h}$ of treatment, quercetin only caused a reduction in the cell population in $\mathrm{G} 0 / \mathrm{G} 1$ phase to $70.53 \%(p<0.001)$ and an increase in the cell population in $S$ phase to $25.72 \%(p<0.001)$, but it had no significant effect on the cell population in $\mathrm{G} 2 / \mathrm{M}$ phase (Fig. $9 \mathrm{~B})$. A significant increase in the cell population in both $\mathrm{S}(39.34 \% ; p<0.001)$ and $\mathrm{G} 2 / \mathrm{M}(39.70 \% ; p<0.001)$ phases was observed in F1-treated cells, where a drop in the cell population to only $20.96 \%(p<0.001)$ in G0/G1 phase compared with the controls. At $72 \mathrm{~h}$ of treatment, quercetin-treated cells constantly underwent cell cycle progression, shifting only from G0/G1 $(61.02 \%, p<0.001)$ to $S(36.88 \%, p<0.001)$ phases with no effect on G2/M phase (Fig. 9C). Similarly, F1-treated cells showed a further reduced cell distribution in $\mathrm{G} 0 / \mathrm{G} 1$ phase $(27.09 \%, p<0.001)$ with increased distribution in both $\mathrm{S}(31.52 \%, p<0.001)$ and $\mathrm{G} 2 / \mathrm{M}(41.39 \%, p<0.001)$ phases at $72 \mathrm{~h}$ of treatment. This phenomenon implied that $\mathrm{F} 1$ induced cell cycle arrest at both $S$ and $\mathrm{G} 2 / \mathrm{M}$ phases, but quercetin induced cell cycle arrest at $\mathrm{S}$ phase only in MDAMB-231.

\section{Apoptosis induction of quercetin- and F1-treated MDA-MB-231}

Analysis of the effect revealed that apoptosis was induced in quercetin-treated MDA-MB-231, but F1 did not induce apoptosis in MDA-MB-231 for $72 \mathrm{~h}$ of treatment compared to the controls (DMSO-treated MDA-MB-231). There was a significant increase in the cell population at the early apoptosis stage, as indicated by an increase in the cell population from $2.99 \%$ in control to $6.61 \%(p<0.001)$ in quercetintreated cells (Fig. 10A). When prolonged quercetin treatment to $48 \mathrm{~h}, 7.71 \%(p<0.001)$ and $5.26 \%(p<$ 0.01 ) of cells were observed in the early apoptosis stage and late apoptosis stage, respectively, compared to $2.43 \%$ of the control in the early apoptosis stage and $2.42 \%$ of the control in the later apoptosis stage (Fig. 10B). The apoptotic effect induced by quercetin at $72 \mathrm{~h}$ of treatment was most significant, as $18.48 \%(p<0.001)$ was found in the early apoptosis stage and $8.13 \%(p<0.05)$ in the late apoptosis stage (Fig. 10C). A significant reduction in cell viability was also observed in the quercetin-treated cells after $72 \mathrm{~h}$ of treatment, suggesting that quercetin was capable of inducing apoptosis compared to $\mathrm{F} 1$ in MDA-MB-231. 


\section{mRNA expression of CYP genes in quercetin- and F1-treated MDA-MB-231}

Analysis only observed the optimum level of CYP1A1 mRNA expression at $48 \mathrm{~h}$ of treatment compared with the control (DMSO-treated MDA-MB-231), where the level of CYP1A1 was upregulated to a much higher extent in quercetin- than in F1-treated MDA-MB-231 (Fig. 11A). The mRNA expression of CYP1A1 in quercetin- and F1-treated cells was upregulated by $20.8-(p<0.001)$ and 6.8 -fold change $(p<0.01)$, respectively, compared with the control at $48 \mathrm{~h}$ of treatment. After treatment for $72 \mathrm{~h}$, CYP1A1 mRNA expression in quercetin-treated cells remained upregulated by 13.2 -fold change $(p<0.001)$. Both quercetin and F1 also showed a similar optimum profile of CYP1B1 mRNA expression with 4.60- $(p<0.01)$ and 3.15 -fold change $(p<0.05)$, respectively, in MDA-MB-231 after $48 \mathrm{~h}$ of treatment (Fig. 11B). The results further showed that significant upregulation of CYP1B1 mRNA expression was observed following $72 \mathrm{~h}$ of quercetin treatment in MDA-MB-231: 3.65-fold change $(p<0.05)$, but F1 had no discernible effect on CYP1B1 mRNA expression. Quercetin also failed to modify CYP2S1 mRNA expression in MDA-MB-231 following $72 \mathrm{~h}$ of treatment. In contrast, F1 increased CYP2S1 mRNA expression in MDA-MB-231 at 24 (1.80-fold change; $p<0.05)$ and $48 \mathrm{~h}(2.85$-fold change; $p<0.001)$ of treatment (Fig. 11C). However, no significant induction of CYP2S1 mRNA expression was observed at $72 \mathrm{~h}$ of F1 treatment. In comparison, quercetin- and F1-treated MDA-MB-231 for $72 \mathrm{~h}$ showed different mRNA expression levels of CYP1A1, CYP1B1 and CYP2S1 in the cells.

\section{Discussion}

The present results demonstrated that the recombinant pPIC3.5K-hTopl plasmid, which contained a copy of the human DNA topoisomerase I (hTopl), was successfully constructed. The Pichia transformants or recombinant yeast (GS115-pPIC3.5K-hTopl), which contained a multi-copy number of hTopl, was also successfully produced via an in vivo strategy. The cell density of GS115-pPIC3.5K-hTopl was likely to be unaffected by the copy number of hTopl. However, the total protein expression and the target enzyme activity of the recombinant yeast were increased in accordance with the increased copy number of hTopl in the host, whereby the yeast that was able to survive at the highest concentration of Geneticin expressed the highest level of total protein and had the highest activity of the enzyme. The recombinant yeast was able to differentiate the growth inhibitory activity of quercetin and $F 1$, indicating that the growth inhibitory activity of pure and plant substances could be predicted by yeast-based screening assay and further confirmed using MTT assay. Quercetin induced cell cycle arrest at S phase only in MDA-MB-231, but the study found F1 induced cell cycle arrest at both $S$ and G2/M phases. Quercetin induced apoptosis in MDA-MB-231, but F1 did not. The F1 showed lower mRNA expression levels of CYP1A1 and CYP1B1 (carcinogenicity). However, the study found a higher mRNA expression level of CYP2S1 (cytotoxicity) in quercetin-treated MDA-MB-231 following $72 \mathrm{~h}$ of treatment.

Pichia is a widely used host system for the expression of heterologous proteins [23]. In addition to the popularity factors described in the Introduction, this system also offers the strong and highly regulated alcohol oxidase promoter, stable integration events in the host chromosomal DNA and efficient techniques for high-density cultivation to express the protein of interest [24]. Therefore, this study utilised this yeast system to express hTopl, whereby the gene encoding the protein of interest is approximately 
2,298 bp. The expression using recombinant yeast containing a single copy number of the target gene was disappointingly low; indeed, the multi-copy number of the gene expression cassette has been one of the most effective strategies to increase the expression of the GOI [9, 25-27]. The recombinant yeast was successfully constructed using the pPIC3.5K vector in this study via the in vivo strategy to determine the effects of gene copy number on cell density, the expression of total protein, and the target enzyme activity in Pichia.

His + Pichia transformants with multi-copy inserts (recombinant yeast) resistant to various concentrations of Geneticin were also successfully selected in this study. However, the selected clones' cell density was likely not affected by the copy number of the target gene in the host, which may interpret as not affect the downstream metabolic activity of the cells. According to previous studies, gene expression induction resulted in excessive plasmid replication that consequently increased the plasmid copy number in the transformants [28-30]. However, this phenomenon contributed also to the host cell metabolic burden $[28,31]$. As a result, the metabolic activity was strongly impaired in the cells, indicated by the decelerated increase in biomass and OD. For the effect of the in vivo strategy, the study found the highest expression level of total protein (as much as $1.76 \mathrm{mg} / \mathrm{ml}$ ) in GS115-pPIC3.5K-hTopl resistant to $1.00 \mathrm{mg} / \mathrm{ml}$ Geneticin at $48 \mathrm{~h}$ of incubation. However, normalisation of the total protein level per hour and per cell density in each transformant was statistically insignificant compared to the total protein level in control. Therefore, the study is continued by investigating the target enzyme activity, whereby the study found the increment of gene copy number to increase the enzyme activity of hTopl produced in GS115pPIC3.5K-hTopl.

A transformant or clone with two identical copies of a gene under the control of an identical promoter, in theory, should produce twice as much protein. However, in practice, increasing the gene dosage does not necessarily increase protein expression. In some cases, e.g., human trypsinogen [32] and Na-ASPI [33], increased the gene dosage reduced the protein expression. Therefore, an optimal level rather than a maximal copy number should be considered due to other possible protein expression bottlenecks, e.g., protein translation, secretion or degradation [32,34-36]. Furthermore, an increased copy number of foreign genes may result in the alteration of normal metabolism in Pichia, leading to a negative influence on the normal cell physiology of multiple-copy recombinant yeast, especially in the case of secretory expression, which includes a reduction in methanol consumption capacity and specific growth rate, decreased cell viability, increased instability of integrated foreign genes or diminished cell secretory ability [37]. For this reason, it is suggested to test the transformants with increasing gene copy numbers and later identify the optimal gene copy number for maximum protein production [34,38]. Although the strategy used in this study did not significantly change the expression of total protein per cell density in each clone, the ability of hTopl expressed by GS115-pPIC3.5K-hTopl resistant to various Geneticin concentrations was increased as the resistance towards Geneticin was increased. This event also further showed that the hTopl expression ability in this study was able to relax supercoiled DNA, and the enzyme activity increased with increasing target gene copy number. 
Incubation of the recombinant yeast (GS115-pPIC3.5K-hTopl) with quercetin and F1 also showed that both substances had different growth inhibitory activity to reduce the growth of the recombinant yeast, which could be further confirmed when MDA-MB-231 was used for the screening. MDA-MB-231 is a poorly differentiated, highly aggressive and invasive breast cancer cell type. It is a model representing triple-negative breast cancer, which is characterised by the lack of oestrogen receptor, progesterone receptor, E-cadherin and HER2 growth factor receptor, but presenting with mutated p53 gene expression [39]. Therefore, MDA-MB-231 is the ideal cell model for investigating the effectiveness of newly developed chemotherapeutic agents. In this study, quercetin and F1 were found to reduce the proliferation of MDAMB-231 by inducing different cell cycle arrest profiles. Regulation of the cell cycle is crucial for the development of healthy cells. Nevertheless, cancerous cells exhibit uncontrolled cell proliferation and evasion of apoptosis resulting from dysfunction of the cell cycle's checkpoint and destruction [40]. Uncontrolled cell growth and apoptosis resistance are the major defects in cancer cells; thus, discovering potential compounds targeting cell cycle mechanisms and apoptotic machinery could be effective against uncontrolled cell proliferation in neoplasia. This study also explored the mechanism by which quercetin and F1 inhibited MDA-MB-231 cell proliferation in different manners.

Quercetin and F1 were also found to exhibit different cell cycle arrest profiles. Red onion peel is known to contain high concentrations of quercetin [41-42] and is able to induce cell cycle arrest and apoptosis in different cancer cells [43], whereas F1 is able to obstruct cell cycle progression in both S and G2/M phases, suggesting that different comprehensive effects of quercetin and F1 in MDA-MB-231. One possible explanation is the presence of different compound compositions in F1, which gives rise to different molecular mechanisms of cell cycle regulation induced by F1. Nguyen's study reported that 20 $\mu \mathrm{M}$ quercetin induced cell cycle arrest at the $S$ and G2/M phases in MDA-MB-231 at $48 \mathrm{~h}$ of treatment [44]. This finding was linked to the increased signalling activities of p21 and GADD45, which contributed to G1/S and G2/M phase arrest, respectively, regulated by p53 [44]. Another study indicated that cell cycle arrest was observed at G2/M phase after treatment of MDA-MB-231 with $100 \mu \mathrm{M}$ quercetin for 24 and 48 h [45]. Nevertheless, Rivera's study showed cell cycle arrest at G2/M phase in MDA-MB-231 after $48 \mathrm{~h}$ of treatment with $15 \mu \mathrm{M}$ quercetin [46]. In this study, cell cycle arrest was observed at S phase only after treatment with quercetin for $48 \mathrm{~h}$, which is slightly in contrast to previously published findings. This difference may be due to variation in the cell treatment concentration, where a higher concentration of quercetin was utilised for the experiments. For apoptosis analysis, the results showed that an apoptotic effect was observed in MDA-MB-231 treated with quercetin, but F1 did not induce apoptosis in MDA-MB231. The induction of apoptotic effects in MBA-MD-231 cells in this study was consistent with other findings using the same cell line [44-47]. This result suggests that cell proliferation inhibition by F1 in MDA-MB-231 occurred through mechanisms other than the apoptosis pathway.

CYP genes have been extensively confirmed to be involved in the metabolism of pro-carcinogenic compounds [48]. Other studies have also shown that the genes encoding these proteins are linked to other cell signalling pathways critical for cell cycle regulation [49]. For instance, the aryl hydrocarbon receptor (AHR), responsible for activating CYP genes' transcription, is a protein that affects cell cycle regulation [50]. Several findings have shown that dietary flavonoids play a role as AHR ligands with either 
antagonist or agonist activity to inhibit cancer cell growth [51-52]. Additionally, flavonoids may also undergo CYP1-mediated oxidative metabolism to become anti-proliferative products [51]. A study has demonstrated anti-proliferative and cytostatic effects of a flavonoid lipid molecule, eupatorine, in breast cancer cells due to the involvement of CYP1-mediated metabolism [53]. The studies showed that cell cycle arrest at G2/M phase induced by eupatorine could be reversed when MDA-MB-468 cells were coincubated with the CYP1 inhibitor acacetin. Another finding by Atherton confirmed that metabolites produced from the isoflavones daidzein and genistein via CYP1A1, CYP1A2 and CYP1B1 metabolism induced an anti-proliferative response in MCF-7 cells [54].

In this study, the analysis of CYP genes showed that quercetin and F1 induced mRNA expression of CYP1A1 and CYP1B1, with the highest level was observed at $48 \mathrm{~h}$ of treatment. This phenomenon corresponded to the initiation of cell cycle arrest at $S$ phase by quercetin in MDA-MB-231. These results also corresponded to the profound changes in cell cycle progression, which was also observed at $48 \mathrm{~h}$ of treatment with further induction of cell cycle arrest at G2/M phase by F1. The finding is supported by numerous studies that revealed the role of quercetin in cancer proliferation in relation to its interaction with CYP family enzymes. For instance, quercetin was shown to be an agonist of CYP1A1 in breast cancer cells [55]. A study by Ciolino also showed that quercetin increases CYP1A1 mRNA through mediation by the AHR receptor [56]. Furthermore, the metabolism of quercetin by the CYP1 enzyme, particularly CYP1A1 and CYP1B1, intensifies their anti-proliferative effects in breast cancer cells [55]. Hence, these results suggested that the anti-proliferative effect of F1 on MDA-MB-231 might be due to the metabolic activities of these CYPs resulting in the production of active metabolites, which indirectly modulate the cell cycle progression and survival of MDA-MB-231. For CYP2S1 gene expression analysis, F1 (but not quercetin) induced significantly high gene expression levels in MDA-MB-231 at 24 and $48 \mathrm{~h}$ of treatment. The selective expression of CYP2S1 in MDA-MB-231 treated with F1 suggested that CYP2S1 likely plays a role in the regulation of F1 anticancer activity, which is likely regulated by AHR [57].

In conclusion, the recombinant yeast produced in this study can provide preliminary information on the growth inhibitory activity of quercetin and $\mathrm{F} 1$, which can then be further confirmed using the MTT assay. The study also explored the basic mechanism by which quercetin and F1 inhibited cell proliferation in MDA-MB-231 via different manners.

\section{Declarations}

\section{Acknowledgements}

The second author would like to thank the sponsorship offered by Agilent Technologies LDA Malaysia. The third author would also like to thank the Graduate Assistant Scheme provided by the Institute of Postgraduate Studies, USM and MyMaster scholarship by Kementerian Pendidikan Malaysia.

\section{Funding}


The Universiti Sains Malaysia Research University Grant Scheme for Individuals (Grant No. 1001/CIPPM/8011103) funded this study.

\section{Conflicts of interest/Competing interests}

The author(s) declare(s) that there is no conflict of interest or competing interests regarding the publication of this article.

\section{Availability of data and materials}

The datasets used and/or analysed during the current study, including the nucleotide sequence of hTopl in the pPIC3.5K-hTopl plasmid that had been deposited to the GenBank (Submission \# 2391932), are available from the corresponding author and can be presented on reasonable request.

\section{Code availability}

Not applicable

\section{Authors' contributions}

Zhao Gang and Khoo Boon Yin contributed to the conception and design of the study. Chao Sin Pei, Nur Adila Fadzil, and Lim Shern Kwok performed the experiments under technical support provided by Chew Ai Lan and Khoo Boon Yin. Also, Khoo Boon Yin interpreted the results, drafted and revised the manuscript. All authors have read and agreed to the final version of this manuscript submitted for publication.

\section{References}

1. Bugreev, D.V. \& Nevinsky, G.A. (2009). Structure and mechanism of action type IA DNA topoisomerases. Biochemistry (Mosc) 74(13), 1467-1481.

https://doi.org/1134/s0006297909130045

2. Liu, L.F. (1989). DNA topoisomerase poisons as antitumor drugs. Rev. Biochem. 58, 351-375. https://doi.org/10.1146/annurev.bi.58.070189.002031

3. Wang, J.C. (1996). DNA Topoisomerases. Rev. Biochem. 65, 635-592. https://doi.org/10.1146/annurev.bi.65.070196.003223

4. Topcu, Z. (2001). DNA topoisomerase as targets for anticancer drugs. Clin. Pharm. Ther. 26(6), 405416. https://doi.org/10.1046/j.1365-2710.2001.00368.x

5. Hurley, L.H. (2002). DNA and its associated processes as targets for cancer therapy. Rev. Cancer 2(3), 188-200. https://doi.org/10.1038/nrc749

6. Coleman, L.W., Perkin, S.L., Bronstein, I.B. \& Holden, J.A. (2000). Expression of DNA topoisomerase I and DNA topoisomerase II-alpha in testicular seminomas. Pathol. 31(6), 728-733. https://doi.org/10.1053/hupa.2000.8462 
7. Berney, D.M., Shamash, J., Gaffney, J., Jordan, S. \& Oliver, R.T.D. (2002). DNA topoisomerase I and II expression in drug resistant germ cell tumours. J. Cancer 87(6), 624-629.

https://doi.org/10.1038/sj.bjc.6600472

8. Jensen, N.F., Agama, K., Roy, A., Smith, D.H., Pfister, T.D., Rømer, M.U., Zhang, H.L., Doroshow, J.H., Knudsen, B.R., Stenvang, J., Brünner, N. \& Pommier, Y. (2016). Characterization of DNA topoisomerase I in three SN-38 resistant human colon cancer cell lines reveal a new pair of resistance-associated mutations. Exp. Clin. Cancer Res. 56. https://doi.org/10.1186/s13046-0160335-x

9. Zhu, T., Guo, M., Tang, Z., Zhang, M., Zhuang, Y., Chu, J. \& Zhang, S. (2009). Efficient generation of multi-copy strains for optimizing secretory expression of porcine insulin precursor in yeast Pichia pastoris. Appl. Microbiol. 107(3), 954-963. https://doi.org/10.1111/j.1365-2672.2009.04279.x

10. Higgins, D.R. (1995). Overview of protein expression in Pichia pastoris. Current Protocols in Protein Science, pp. 5.7.1-5.7.16. New York: John Wiley \& Sons.

https://doi.org/1002/0471140864.ps0507s02

11. Cereghino, J.L. \& Cregg, J.M. (2000). Heterologous protein expression in the methylotrophic yeast Pichia pastoris. FEMS Microbiol. Rev. 24(1), 45-66. https://doi.org/1111/j.15746976.2000.tb00532.x

12. Cregg, J.M, \& Higgins, D.R. (1995). Production of foreign protein in the yeast Pichia pastoris. Can. J. Bot. 73(S1), 891-897. https://doi.org/10.1139/b95-336

13. Brierley, R.A., Bussuneau, C., Kosson, R., Melton, A. \& Siegel, R.S. (1990). Fermentation development of recombinant Pichia pastoris expressing the heterologous gene: bovine lysozyme. Ann. N. Y. Acad. Sci. 589, 350-362. https://doi.org/1111/j.1749-6632.1990.tb24257.x

14. Zhang, W., Inan, M. \& Meagher, M.M. (2000). Fermentation strategies for recombinant protein expression in the methylotrophic yeast Pichia pastoris. Biotechnol. Bioprocess Eng. 5(4), 275-287. https://doi.org/10.1007/BF02942184

15. Cereghino, G.P., Cereghino, J.L., Ilgen, C. \& Cregg, J.M. (2002). Production of recombinant proteins in fermenter cultures of the yeast Pichia pastoris. Curr. Opin. Biotechnol. 13(4), 329-332. https://doi.org/1016/s0958-1669(02)00330-0

16. Xin, J., Wan-Mahtar, W.N.A., Siah, P.C., Miswan, N. \& Khoo, B.Y. (2019). Pichia pastoris strain SMD1168H expressing DNA topoisomerase I displays the potential to be used for preliminary screening of effective adjuvants for combined use with breast cancer chemotherapy drugs. Mol. Med. Rep. 19(6), 5368-5376. https://doi.org/3892/mmr.2019.10201

17. Nicastro, H.L., Ross, S.A. \& Milner, J.A. (2015). Garlic and onions: their cancer prevention properties. Cancer Prev. Res. (Phila) 8(3), 181-189. https://doi.org/1158/1940-6207.CAPR-14-0172

18. Desai, G., Schelske-Santos, M., Nazario, C.M., Rosario-Rosado, R.V., Mansilla-Rivera, I., RamirezMarrero, F., Nie, J., Myneni, A.A., Zhang, Z.F., Freudenheim, J.L. \& Mu, L. (2020). Onion and garlic intake and breast cancer, a case-control study in Puerto Rico. Cancer 72(5), 791-800. https://doi.org/10.1080/01635581.2019.1651349 
19. Chan, M.K., Lim, S.K., Miswan, N., Chew, A.L., Noordin, R. \& Khoo, B.Y. (2018). Expression of stable and active human DNA topoisomerase I in Pichia pastoris. Protein Expr. Purif. 141, 52-62. https://doi.org/1016/j.pep.2017.09.003

20. Yang, , Zhou, H., Lu, Y., Lin, Y. \& Zhou, S. (2004). Comparing expression of different forms of human DNA topoisomerase I in Pichia pastoris. Enzyme Microb. Technol. 34(2), 139-146. https://doi.org/10.1016/j.enzmictec.2003.09.006

21. Chao, S.P., Siah, P.C., Lim, S.K., Peh, K.K., Ong, M.T. \& Khoo, B.Y. (2020). The cellular activities of the sub-fraction of red onion peel crude ethanolic extract in MDA-MB-231 cells. Res. 12(4), 416-423. https://doi.org/10.4103/pr.pr_20_20

22. Livak, K.J. \& Schmittgen, T.D. (2001). Analysis of relative gene expression data using real-time quantitative PCR and the 2(-Delta Delta C(T)) method. Methods 25(4), 402https://doi.org/10.1006/meth.2001.1262

23. Cregg, J.M., Cereghino, J.L., Shi, J. \& Higgins, D.R. (2000). Recombinant protein expression in Pichia pastoris. Mol. Biotechnol. 16(1), 23-52. https://doi.org/10.1385/MB:16:1:23

24. Cereghino, G.P. \& Cregg, J.M. (1999). Applications of yeast in biotechnology: protein production and genetic analysis. Curr. Opin. Biotechnol. 10(5), 422-427. https://doi.org/1016/s0958-1669(99)00004$X$

25. Sreekrishna, K., Potenz, R.H., Cruze, J.A., McCombie, W.R., Parker, K.A., Nelles, L., Mazzaferro, P.K., Holden, K.A., Harrison, R.G., Wood, P.J., Phelps, D.A., Hubbard, C.E. \& Fuke, M. (1988). High level expression of heterologous proteins in methylotrophic yeast Pichia pastoris. J. Basic Microbiol. 28(4), 256-278. https://doi.org/1002/jobm.3620280410

26. Romanos, M.A., Clare, J.J., Beesley, K.M., Rayment, F.B., Ballantine, S.P., Makoff, A.J., Dougan, G., Fairweather, N.F. \& Charles, I.G. (1991). Recombinant Bordetella pertussis percatctin (P69) from the yeast Pichia pastoris: high-level production and immunological properties. Vaccine 9(12), 901-906. https://doi.org/1016/0264-410x(91)90011-t

27. Khan, M.A., Hassan, N., Ahmad, N., Khan, M.I., Zafar, A.U., Khan, F. \& Husnain, T. (2014). Studies to analyse the relationship between IFNa2b gene dosage and its expression, using a Pichia pastorisbased expression system. Yeast 31(1), 13-28. https://doi.org/1002/yea.2990

28. Grabherr, R., Nilsson, E., Striedner, G. \& Bayer, K. (2002). Stabilizing plasmid copy number to improve recombinant protein production. Bioeng. 77(2), 142-147. https://doi.org/10.1002/bit.10104

29. Rahmen, N., Schlupp, C.D., Mitsunaga, H., Fulton, A., Aryani, T., Esch, L., Schaffrath, U., Fukuzaki, E., Jaeger, K.E. \& Büchs, J. (2015a). A particular silent codon exchange in a recombinant gene greatly influences host cell metabolic activity. Cell Fact. 14, 156. https://doi.org/10.1186/s12934-015-0348-8

30. Rahmen, N., Fulton, A., Ihling, N., Magni, M., Jaeger, K.E. \& Büchs, J. (2015b). Exchange of single amino acids at different positions of a recombinant protein affects metabolic burden in Escherichia coli. Cell Fact. 14, 10. https://doi.org/10.1186/s12934-015-0191-y

31. Palomares, L., Estrada-Mondaca, S. \& Ramirez, O. (2004). Production of Recombinant Proteins Recombinant Gene Expression. In P. Balbas \& A. Lorence (Eds.), Recombinant Gene Expression, pp. 
15-51. Humana Press.

32. Hohenblum, H., Gasser, B., Maurer, M., Borth, N. \& Mattanovich, D. (2004). Effects of gene dosage, promoters and substrates on unfolded protein stress of recombinant Pichia pastoris. Biotechnol. Bioeng. 85(4), 367-375. https://doi.org/1002/bit.10904

33. Inan, M., Asryasomayajula, D., Sinha, J. \& Meagher, M.M. (2006). Enhancement of protein secretion in Pichia pastoris by overexpression of protein disulfide isomerase. Biotechnol. Bioeng. 93(4), 771-778. https://doi.org/1002/bit.20762

34. Higgins, D.R. \& Cregg, J.M. (1998). Pichia Protocols. Totowa, NJ: Humana Press.

35. Cos, O., Serrano, A., Montesinos, J.L., Ferrer, P., Cregg, J.M. \& Valero, F. (2005). Combined effect of the methanol utilization (Mut) phenotype and gene dosage on recombinant protein production in Pichia pastoris fed-batch cultures. J. Biotechnol. 116(4), 321-335.

https://doi.org/1016/j.jbiotec.2004.12.010

36. Liu, H., Qin, Y., Huang, Y., Chen, Y., Cong, P. \& He, Z. (2014). Direct evaluation of the effect of gene dosage on secretion of protein from yeast Pichia pastoris by expression EGFP. J. Microbiol. Biotechnol. 24(2), 144-151. https://doi.org/4014/jmb.1308.08010

37. Zhu, T., Guo, M., Zhuang, Y., Chu, J. \& Zhang, S. (2011). Understanding the effect of foreign gene dosage on the physiology of Pichia pastoris by transcriptional analysis of key genes. Microbiol. Biotechnol. 89(4), 1127-1135. https://doi.org/10.1007/s00253-010-2944-1

38. Sreekrishna, K., Brankamp, R.G., Kropp, K.E., Blankenship, D.T., Tsay, J.T., Smith, P.L., Wierschke, J.D., Subramaniam, A. \&Birkenberger, L.A. (1997). Strategies for optimal synthesis and secretion of heterologous proteins in the methylotrophic yeast Pichia pastoris. Gene 190(1), 55-62. https://doi.org/10.1016/S0378-1119(96)00672-5

39. Welsh, J. (2013). Animal models for studying prevention and treatment of breast cancer. In P. M. Conn (Ed), Animal Models for the Study of Human Disease. pp. 997-1018. Cambridge, Massachusetts: Academic Press.

40. Hanahan, D. \& Weinberg, R.A. (2011). Hallmarks of cancer: The next generation. Cell 144(5), 646-674. https://doi.org/1016/j.cell.2011.02.013

41. Škerget, , Majhenič, L., Bezjak, M. \& Knez, Ž. (2009). Antioxidant, radical scavenging and antimicrobial activities of red onion (Allium cepa L) skin and edible part extracts. Chem. Biochem. Eng. Q. 23(4), 435-444.

42. Zhang, S., Deng, P., Xu, Y., Lü, S. \& Wang, J. (2016). Quantification and analysis of anthocyanin and flavonoids compositions, and antioxidant activities in onions with three different colours. Integr. Agric. 15(9), 2175-2181. https:// doi.org/10.1016/S2095-3119(16)61385-0

43. Srivastava, S., Somasagara, R.R., Hegde, M., Nishana, M., Tadi, S.K., Srivastava, M., Choudhary, B. \& Raghavan, S.C. (2016). Quercetin, a Natural Flavonoid Interacts with DNA, Arrests Cell Cycle and Causes Tumor Regression by Activating Mitochondrial Pathway of Apoptosis. Sci. Rep. 6, 24049. https://doi.org/1038/srep24049 
44. Nguyen, L.T., Lee, Y., Sharma, A.R., Park, J.B., Jagga, S., Sharma, G., Lee, S.S. \& Nam, J.S. (2017). Quercetin induces apoptosis and cell cycle arrest in triple-negative breast cancer cells through modulation of Foxo3a activity. Korean J. Physiol. Pharmacol. 21(2), 205-213. https://doi.org/10.4196/kjpp.2017.21.2.205

45. Wang, R., Yang, L., Li, S., Ye, D., Yang, L., Liu, Q., Zhao, Z., Cai, Q., Tan, J. \& Li, X. (2018). Quercetin inhibits breast cancer stem cells via downregulation of Aldehyde Dehydrogenase 1A1 (ALDH1A1), Chemokine Receptor Type 4 (CXCR4), Mucin 1 (MUC1), and Epithelial Cell Adhesion Molecule (EpCAM). Sci. Monit. 24, 412-420. https://doi.org/10.12659/msm.908022

46. Rivera, A.R., Castillo-Pichardo, L., Gerena, Y. \& Dharmawardhane, S. (2016). Anti-breast cancer potential of quercetin via the Akt/AMPK/ Mammalian Target of Rapamycin (mTOR) signalling cascade. PLoS ONE 11(6), e0157251. https://doi.org/1371/journal.pone.0157251

47. Chien, S.Y., Wu, Y.C., Chung, J.G., Yang, J.S., Lu, H.F., Tsou, M.F., Wood, W.G., Kuo, S.J. \& Chen, D.R. (2009). Quercetin-induced apoptosis acts through mitochondrial- and caspase-3-dependent pathways in human breast cancer MDA-MB-231 cells. Exp. Toxicol. 28(8), 493-503. https://doi.org/10.1177/0960327109107002

48. Elfaki, I., Mir, R., Almutairi, F.M. \& Duhier, F.M.A. (2018). Cytochrome P450: Polymorphisms and Roles in Cancer, Diabetes and Atherosclerosis. Asian Pac. J. Cancer Prev. 19(8), 2057-2070. https://doi.org/22034/APJCP.2018.19.8.2057

49. Santes-Palacios, R., Ornelas-Ayala, D., Cabañas, N., Marroquín-Pérez, A., Hernández-Magaña, A., Olguín-Reyes, S.D.R., Camacho-Carranza, R. \& Espinosa-Aguirre, J.J. (2016). Regulation of Human Cytochrome P4501A1 (hCYP1A1): A Plausible Target for Chemoprevention? Biomed. Res. Int. 2016, 5341081. https://doi.org/1155/2016/5341081

50. Murray, I.A., Patterson, A.D. \& Perdew, G.H. (2014). Aryl hydrocarbon receptor ligands in cancer: friend and foe. Rev. Cancer 14(12), 801-814. https://doi.org/10.1038/nrc3846

51. Androutsopoulos, V.P., Papakyriakou, A., Vourloumis, D., Tsatsakis, A.M. \& Spandidos, D.A. (2010). Dietaryflavonoids in cancer therapy and prevention: substrates and inhibitors of cytochrome P450 CYP1 enzymes. Ther. 126(1), 9-20. https://doi.org/10.1016/j.pharmthera.2010.01.009

52. Yang, T., Feng, Y., Chen, L., Vaziri, N.D. \& Zhao, Y. (2019). Dietary natural flavonoids treating cancer by targeting aryl hydrocarbon receptor. Rev. Toxicol. 49(5), 445-460. https://doi.org/10.1080/10408444.2019.1635987

53. Androutsopoulos, V., Arroo, R.R.J., Hall, J.F., Surichan, S. \& Potter, G.A. (2008). Antiproliferative and cytostatic effects of the natural product eupatorin on MDA-MB-468 human breast cancer cells due to CYP1-mediated metabolism. Breast Cancer Res. 10(3), https://doi.org/10.1186/bcr2090

54. Atherton, K.M., Mutch, E. \& Ford, D. (2006). Metabolism of the soyabean isoflavone daidzein by CYP1A2 and the extra-hepatic CYPs 1A1 and 1B1 affects biological activity. Pharmacol. 72(5), 624631. https://doi.org/10.1016/j.bcp.2006.05.015

55. Wilsher, N.E., Arroo, R.R., Matsoukas, M.-T., Tsatsakis, A.M., Spandidos, D.A. \& Androutsopoulos, V.P. (2017). Cytochrome P450 CYP1 metabolism of hydroxylated flavones and flavonols: Selective 
bioactivation of luteolin in breast cancer cells. Food Chem. Toxicol. 110, 383-394.

https://doi.org/1016/j.fct.2017.10.051

56. Ciolino, H.P., Daschner, P.J. \& Yeh, G.C. (1999). Dietary flavonols quercetin and kaempferol are ligands of the aryl hydrocarbon receptor that affect CYP1A1 transcription differentially. J. 340(Pt 3), 715-722.

57. Saarikoski, S.T., Rivera, S.P., Hankinson, O. \& Husgafvel-Pursiainen, K. (2005). CYP2S1: a short review. Appl. Pharmacol. 207(2 Suppl), 62-69. https://doi.org/10.1016/j.taap.2004.12.027

\section{Figures}


Clone gene of interest into pPIC3.5K plasmid
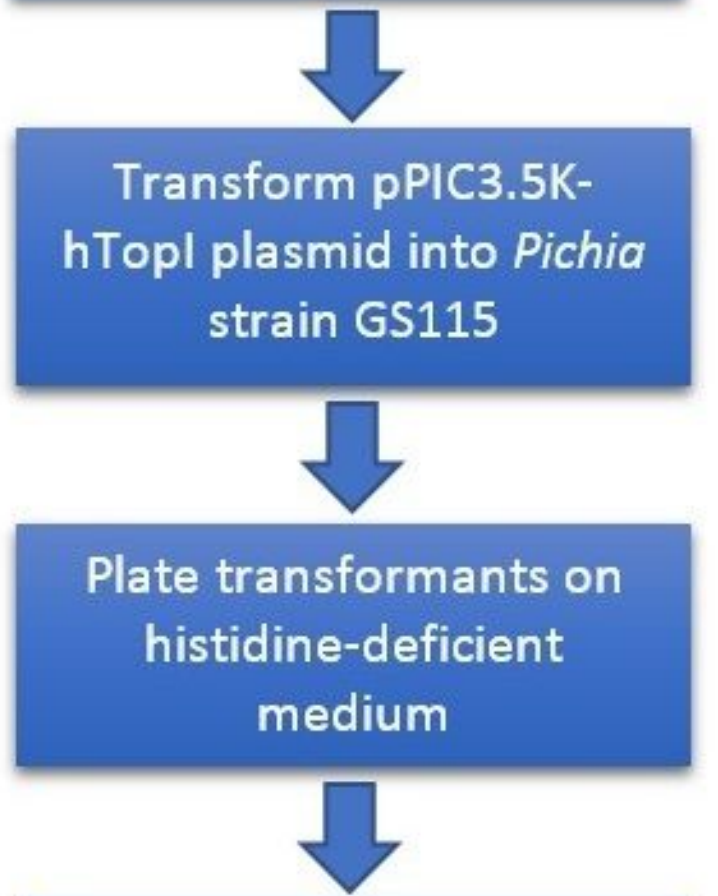

Screen transformants

containing different copy number pPIC3.5K-hTopl on various concentration of Geneticin

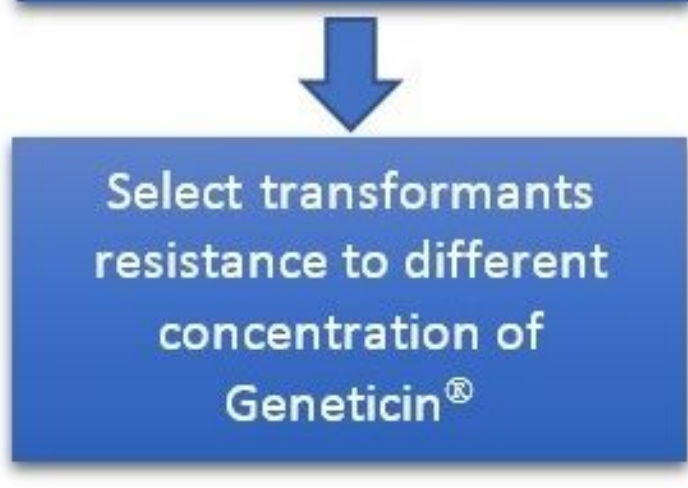

\section{Figure 1}

Schematic overview of in vivo strategy to produce recombinant yeast with multiple copies of pPIC3.5KhTopl in Pichia. 


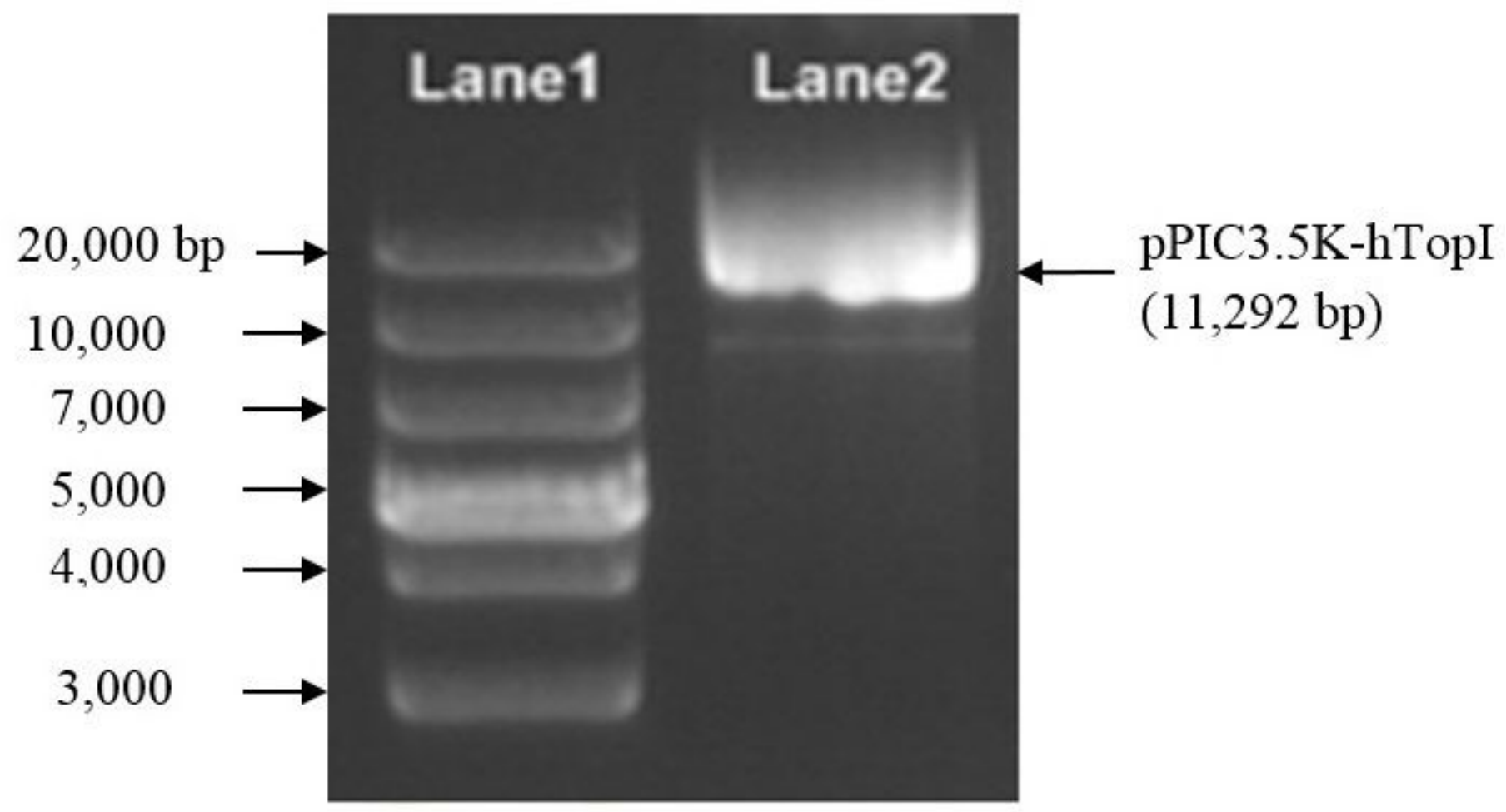

Figure 2

Construction of recombinant plasmid via in vivo strategy. The $0.7 \%$ agarose gel electrophoresis of constructed recombinant pPIC3.5K-hTopl plasmid DNA. Lane 1: GeneRuler 1 kb Plus DNA Ladder. Lane 2: Recombinant pPIC3.5K-hTopI plasmid. Cropped image of gel; full-length gel can be presented on reasonable request. 
>Seq1 [organism=homo sapiens] [clone=1] DNA topoisomerase I gene, cds CAAATGCGAACTTAGGCTGTTACACAACTGCTGGGGTCTGTTCTCGCCGCCCGCCCGGCAGTCAGGCAGCG TCGCCGCCGTGGTAGCAGCCTCAGCCGTTTCTGGAGTCTCGGGCCCACAGTCACCGCCGCTTACCTGCGCC TCCTCGAGCCTCCGGAGTCCCCGTCCGCCCGCACAGGCCGGTTCGCCGTCTGCGTCTCCCCCACGCCGCCT CGCCTGCCGCCGCGCTCGTCCCTCCGGGCCGACATGAGTGGGGACCACCTCCACAACGATTCCCAGATCGA AgCGgATTTCCGATGAATGATTCTCATAAACACAAAGATAAACACAAAGATCGAGAACACCGGCACAAAG AACACAAGAAGGAGAAGGACCGGGAAAAGTCCAAGCATAGCAACAGTGAACATAAAGATTCTGAAAAGAAA CACAAAGAGAAGGAGAAGACCAAACACAAAGATGGAAGCTCAGAAAAGCATAAAGACAAACATAAAGACAG AGACAAGGAAAAACGAAAAGAGGAAAAGGTTCGAGCCTCTGGGGATGCAAAAATAAAGAAGGAGAAGGAAA ATGGCTTCTCTAGTCCACCACAAATTAAAGATGAACCTGAAGATGATGGCTATTTTGTTCCTCCTAAAGAG GATATAAAGCCATTAAAGAGACCTCGAGATGAGGATGATGCTGATTATAAACCTAAGAAAATTAAAACAGA AGATACCAAGAAGGAGAAGAAAAGAAAACTAGAAGAAGAAGAGGATGGTAAATTGAAAAAACCCAAGAATA AAGATAAAGATAAAAAAGTTCCTGAGCCAGATAACAAGAAAAAGAAGCCGAAGAAAGAAGAGGAACAGAAG TGGAAATGGTGGGAAGAAGAGCGCTATCCTGAAGGCATCAAGTGGAAATTCCTAGAACATAAAGGTCCAGT АтTTGCCCCACCATATGAGCCTCTTCCAGAGAATGTCAAGTTTATTATGATGGTAAAGTCATGAAGCTGA GCCCCAAAGCAGAGGAAGTAGCTACGTTCTTTGCAAAAATGCTCGACCATGAATATACTACCAAGGAAATA TTTAGGAAAAATTTTTTAAAGACTGGAGAAAGGAAATGACTAATGAAGAGAAGAATATTATCACCAACCT AAgCAAATGTGATTTTACCCAGATGAGCCAGTATTTCAAAGCCCAGACGGAAGCTCGGAAACAGATGAGCA AGgAAGAGAAACTGAAAATCAAAGAGGAGAATGAAAAATTACTGAAAGAATATGGATTCTGTATTATGGAT AACCACAAAGAGAGGATTGCTAACTTCAAGATAGAGCCTCCTGGACTTTTCCGTGGCCGCGGCAACCACCC CAAGATGGGCATGCTGAAGAGACGAATCATGCCCGAGGATATAATCATCAACTGTAGCAAAGATGCCAAGG TTCСTTCTCCTCCTCCAGGACATAAGTGGAAAGAAGTCCGGCATGATAACAAGGTTACTTGGCTGGTTTCC TGGACAGAGAACATCCAAGGTTCCATTAAATACATCATGCTTAACCCTAGTTCACGAATCAAGGGTGAGAA GGACTGGCAGAAATACGAGACTGCTCGGCGGCTGAAAAAATGTGTGGACAAGATCCGGAACCAGTATCGAG AAGACTGGAAGTCCAAAGAGATGAAAGTCCGGCAGAGAGCTGTAGCCCTGTACTTCATCGACAAGCTTGCT CTGAGAGCAGGCAATGAAAAGGAGGAAGGAGAAACAGCGGACACTGTGGGCTGCTGCTCACTTCGTGTGGA GCACATCAATCTACACCCAGAGTTGGATGGTCAGGAATATGTGGTAGAGTTTGACTTCCTCGGGAAGGACT CCATCAGATACTATAACAAGGTCCCTGTTGAGAAACGAGTTTTTAAGAACCTACAACTATTTATGGAGAAC AAGCAGCCCGAGGATGATCTTTTGATAGACTCAATACTGGTATTCTGAATAAGCATCTTCAGGATCTCAT GGAGGGCTTGACAGCCAAGGTATTCCGTACATACAATGCCTCCATCACGCTACAGCAGCAGCTAAAAGAAC TGACAGCCCCGGATGAGAACATCCCAGCGAAGATCCTTTCTTATAACCGTGCCAATCGAGCTGTTGCAATT CTTTGTAACCATCAGAGGGCACCACCAAAAACTTTTGAGAAGTCTATGATGAACTTGCAAACTAAGATTGA TGCCAAGAAGGAACAGCTAGCAGATGCCCGGAGAGACCTGAAAAGTGCTAAGGCTGATGCCAAGGTCATGA AGGATGCAAAGACGAAGAAGGTAGTAGAGTCAAAGAAGAAGGCTGTTCAGAGACTGGAGGAACAGTTGATG AAGCTGGAAGTTCAAGCCACAGACCGAGAGGAAAATAAACAGATTGCCCTGGGAACCTCCAAACTCAATTA TCTGGACCCTAGGATCACAGTGGCTTGGTGCAAGAAGTGGGGTGTCCCAATTGAGAAGATTTACAACAAAA CCCAGCGGGAGAAGTTTGCCTGGGCCATTGACATGGCTGATGAAGACTATGAGTTTTAGCCAGTCTCAAGA GGCAGAGTTCTGTGAAGAGGAACAGTGTGGTTTGGGAAAGATGG

\section{Figure 3}

Nucleotide sequence of hTopl in the pPIC3.5K-hTopl plasmid. The sequence was identified by sequencing and had been deposited to the GenBank (Submission \# 2391932). The sequence can be presented at a reasonable request. 
(A) $0.25 \mathrm{mg} / \mathrm{ml} \mathrm{Geneticin}{ }^{\circledR}$

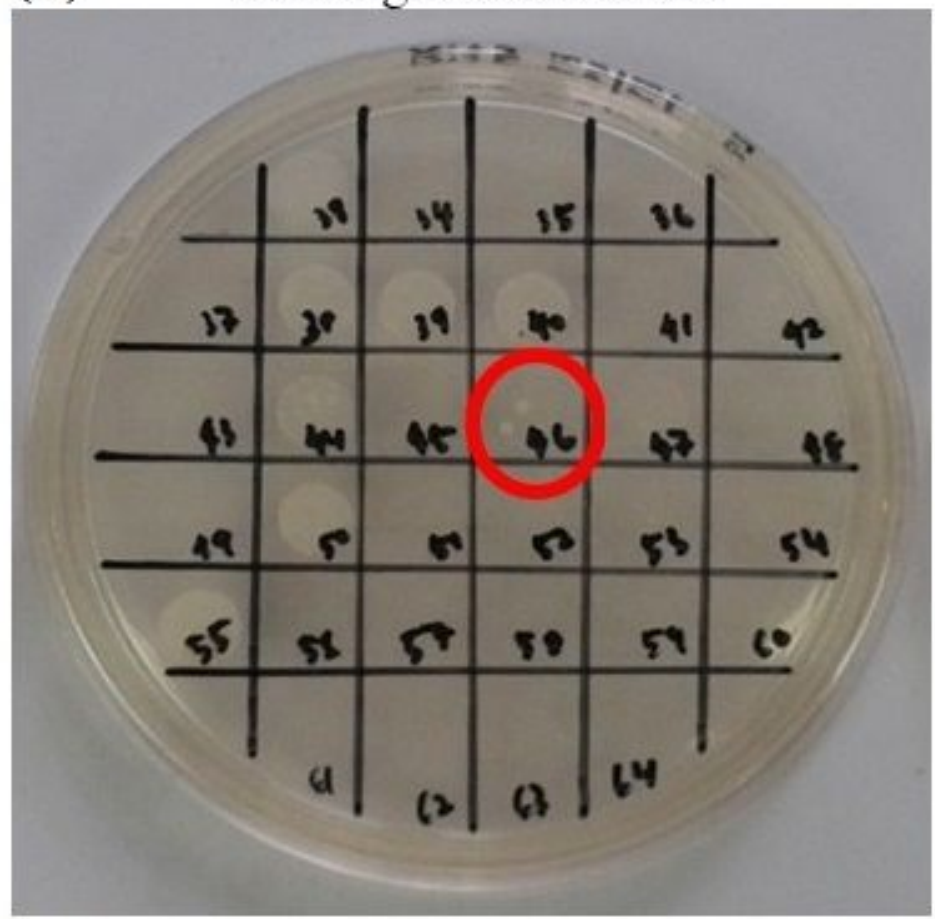

(C)

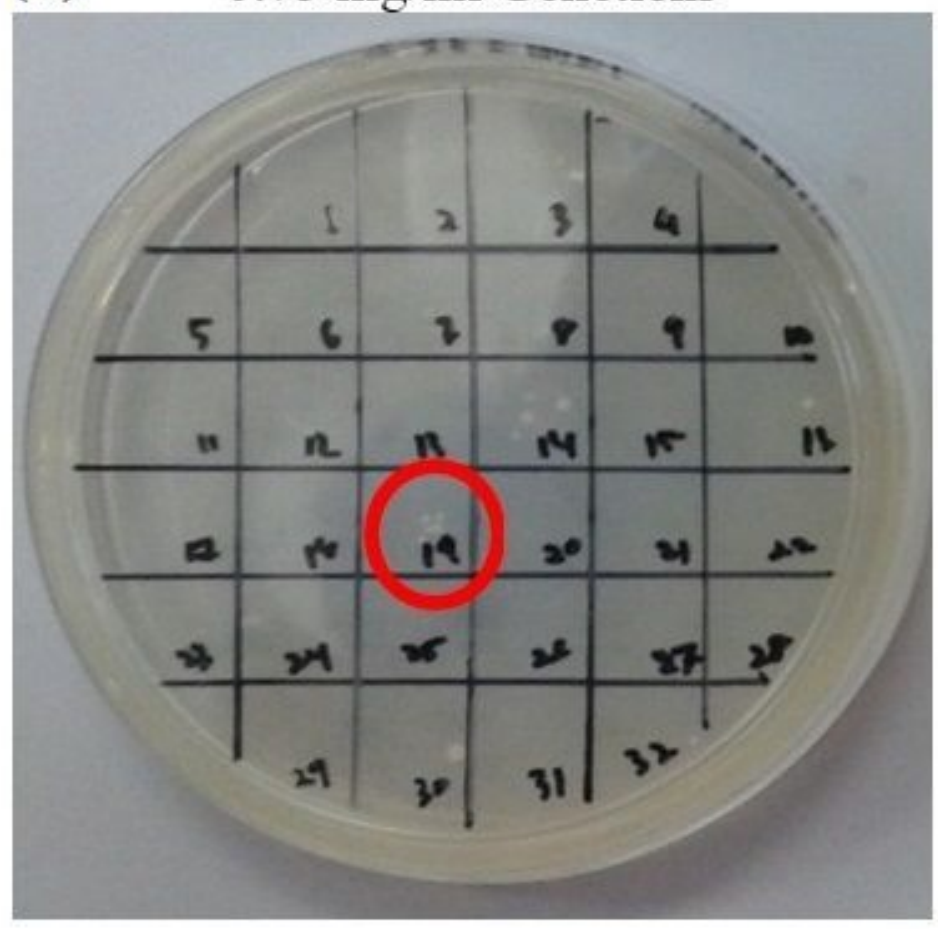

(B) $0.50 \mathrm{mg} / \mathrm{ml} \mathrm{Geneticin}{ }^{\circledR}$

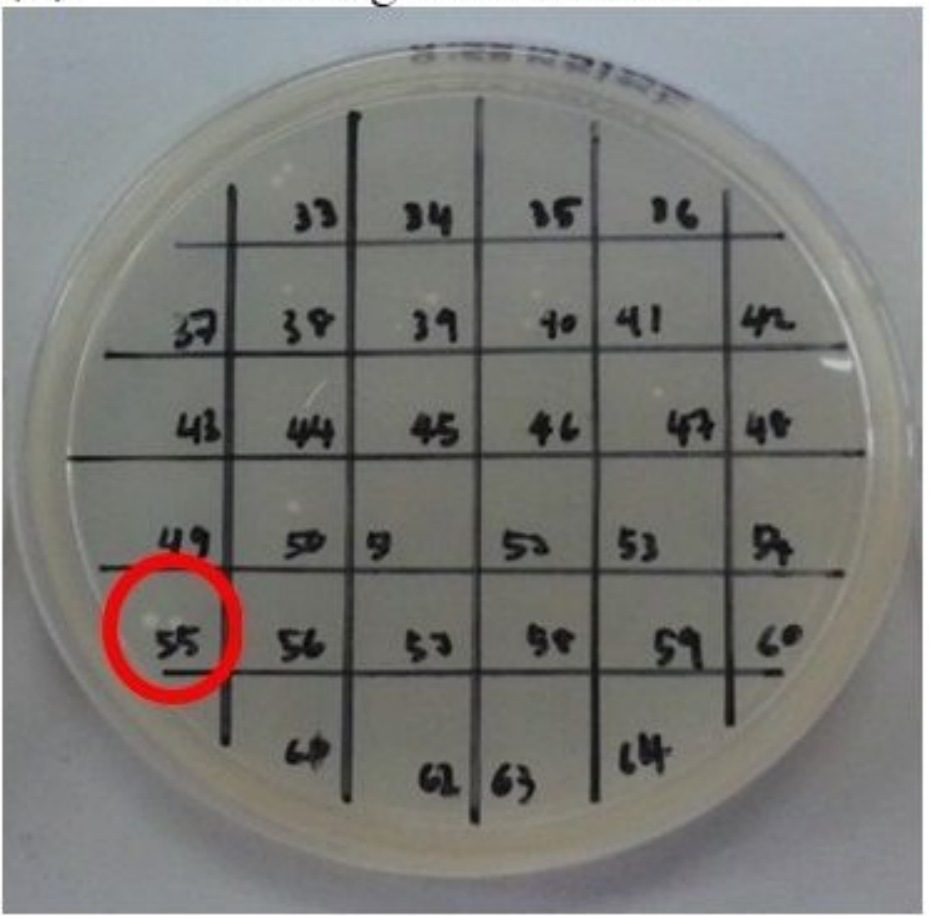

(D)

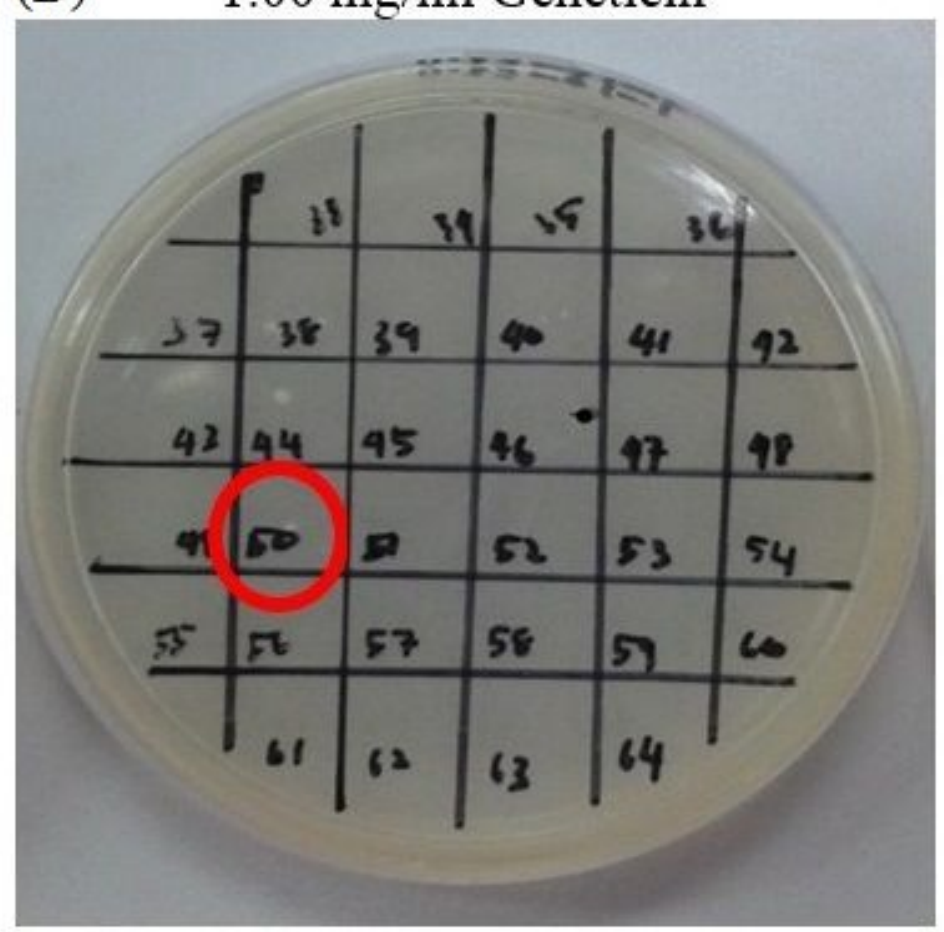

\section{Figure 4}

Screening of GS115-pPIC3.5K-hTopl on YPD agar containing various Geneticin concentrations. The concentrations of antibiotic used on the YPD agar were (A) 0.25 , (B) $0.50,(C) 0.75$, and (D) $1.00 \mathrm{mg} / \mathrm{ml}$. The grid circled in red indicates the clone resistant to the antibiotic's particular concentration in the agar plate. Images of agar gel were derived from the same experiment and were processed in parallel. 

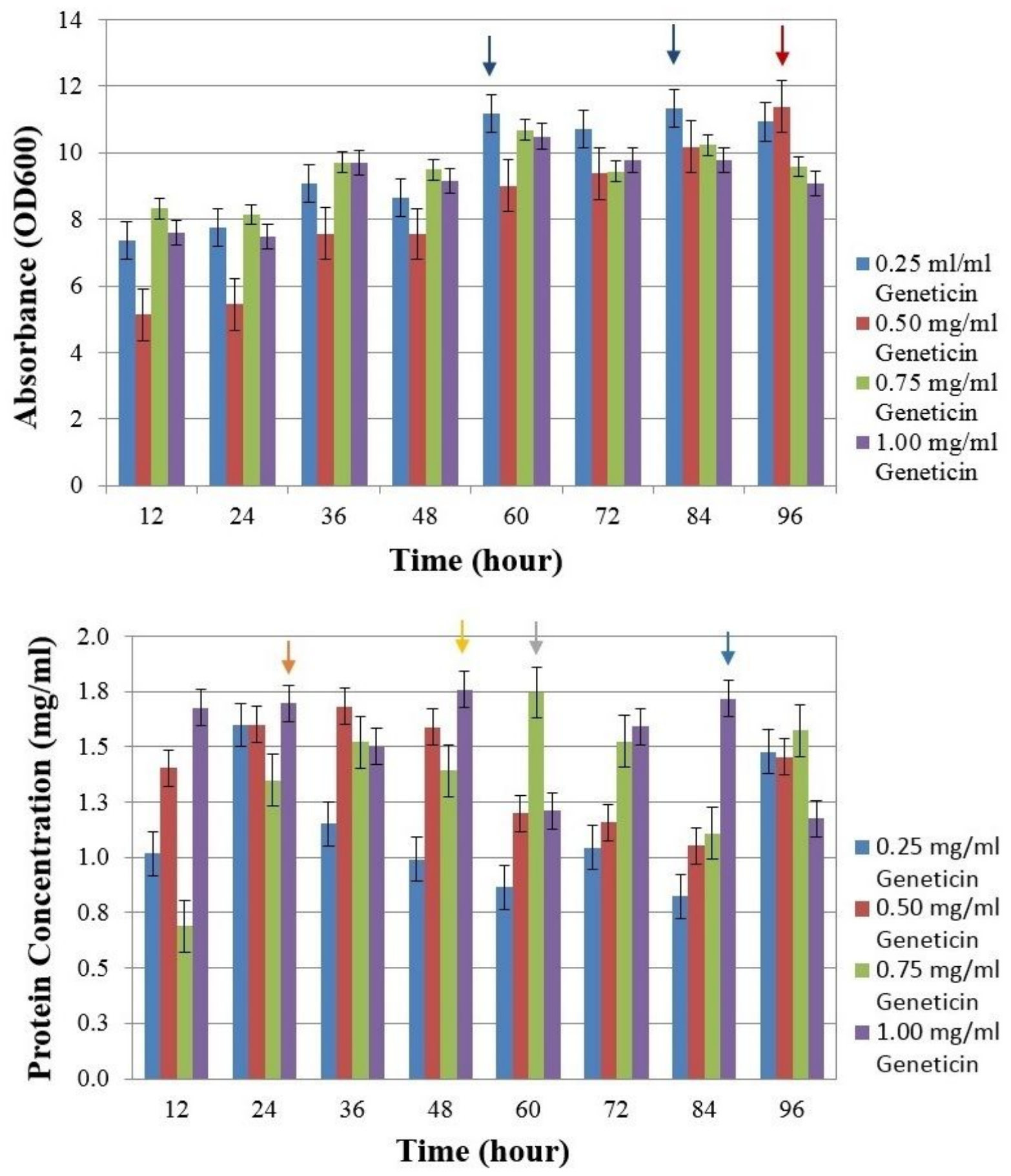

\section{Figure 5}

Cell growth and total protein expression of GS115-pPIC3.5K-hTopl. (A) Cell growth of the transformants after $96 \mathrm{~h}$ of culture. The density of GS115-pPIC3.5K-hTopl resistant to various Geneticin concentrations on agar plates was measured by spectrophotometry. (B) Total protein expression of the transformants at $96 \mathrm{~h}$ of incubation. The Bio-Rad protein assay measured the expression level of total protein in GS115- 
pPIC3.5K-hTop1 resistant to various Geneticin concentrations. All data represent the mean \pm SD of 3 replications.

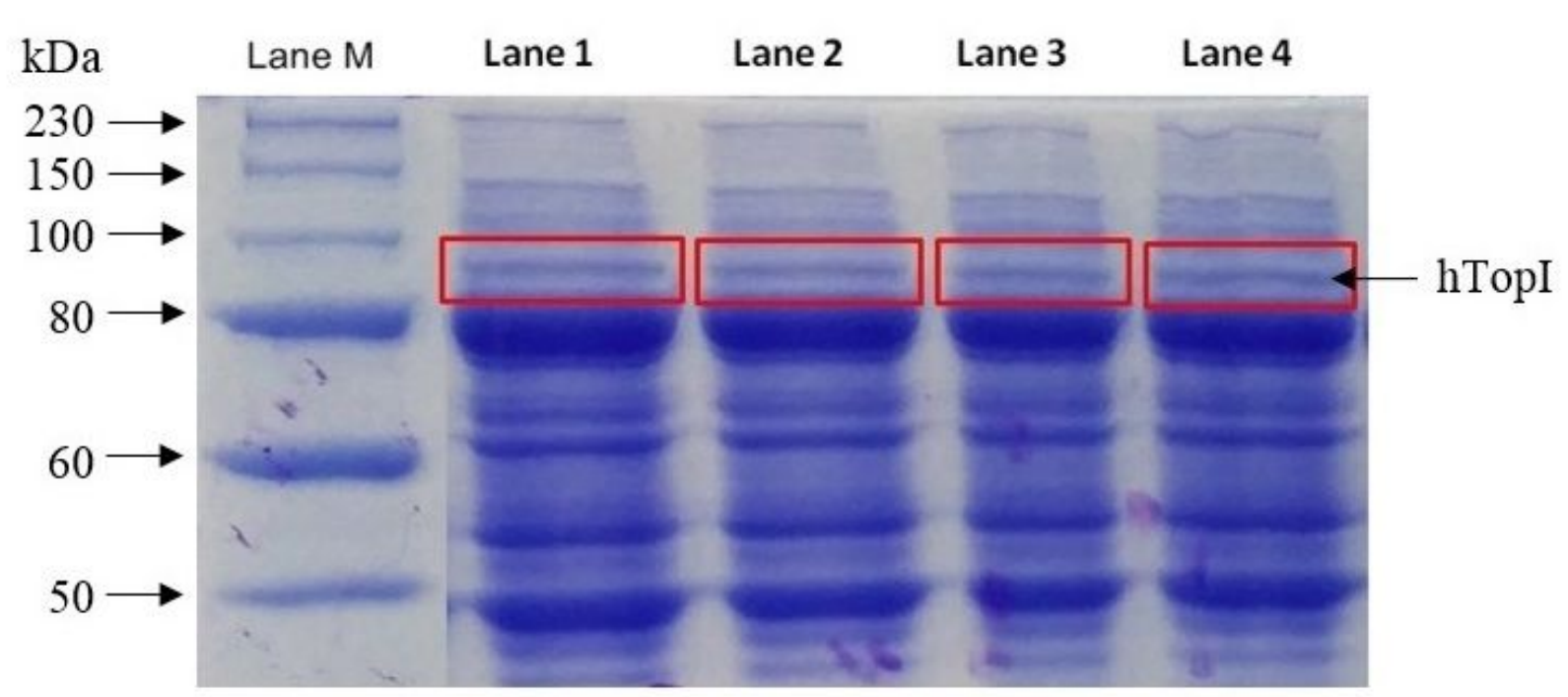

\section{Lane 1 Lane 2 Lane 3 Lane 4}

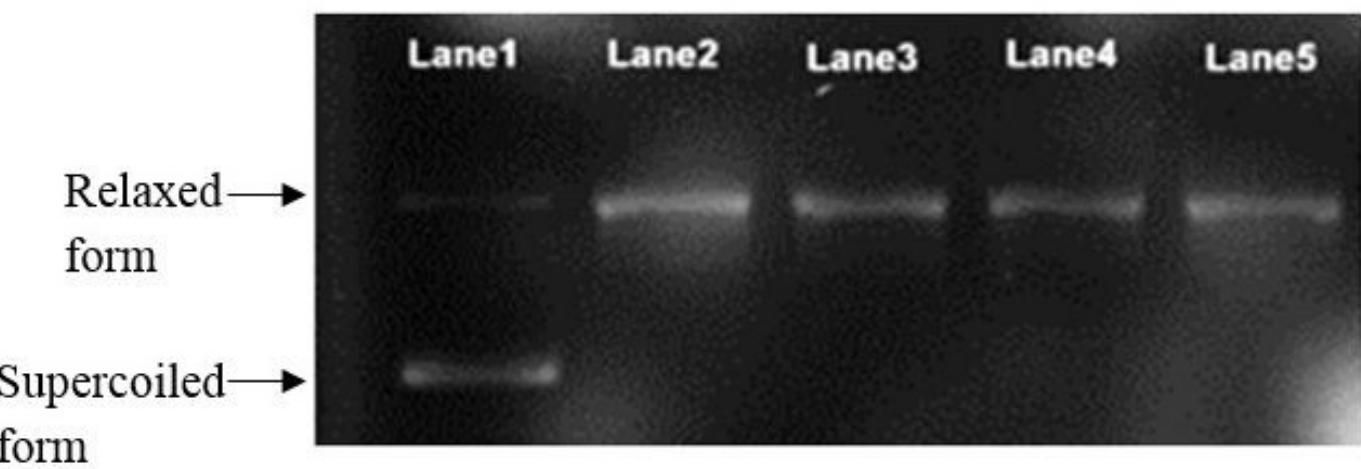

\section{Figure 6}

Specific protein expression for selected clones. (A) SDS-PAGE of total protein extracted from GS115pPIC3.5K-hTopl resistant to various Geneticin concentrations. Lane M: Protein molecular weight marker (Bio-Rad, USA). Lane 1: Clone resistant to $1.00 \mathrm{mg} / \mathrm{ml}$ Geneticin, collected at $24 \mathrm{~h}$ of incubation. Lane 2: 
Clone resistant to $1.00 \mathrm{mg} / \mathrm{ml}$ Geneticin, collected at $48 \mathrm{~h}$ of incubation. Lane 3: Clone resistant to 0.75 $\mathrm{mg} / \mathrm{ml}$ Geneticin, collected at $60 \mathrm{~h}$ of incubation. Lane 4: Clone resistant to $1.00 \mathrm{mg} / \mathrm{ml}$ Geneticin, collected at $84 \mathrm{~h}$ of incubation. (B) Western blotting for hTopl protein detection in GS115-pPIC3.5K-hTopl resistant to various Geneticin concentrations. Lane 1: Clone resistant to $1.00 \mathrm{mg} / \mathrm{ml}$ Geneticin, collected at $24 \mathrm{~h}$ of incubation. Lane 2: Clone resistant to $1.00 \mathrm{mg} / \mathrm{ml}$ Geneticin, collected at $48 \mathrm{~h}$ of incubation. Lane 3: Clone resistant to $0.75 \mathrm{mg} / \mathrm{ml}$ Geneticin, collected at $60 \mathrm{~h}$ of incubation. Lane 4: Clone resistant to $1.00 \mathrm{mg} / \mathrm{ml}$ Geneticin, collected at $84 \mathrm{~h}$ of incubation. (C) The $1.0 \%$ agarose gel electrophoresis of the enzyme activity of hTopl in the clones that resistant to various Geneticin concentrations. Lane 1:

Supercoiled DNA of pBR322 incubated without hTopl. Lane 2: Supercoiled DNA of pBR322 incubated with hTopl from the clone resistant to $0.25 \mathrm{mg} / \mathrm{ml}$ Geneticin $(24 \mathrm{~h})$. Lane 3: Supercoiled DNA of pBR322 incubated with hTopl from the clone resistant to $0.50 \mathrm{mg} / \mathrm{ml}$ Geneticin $(36 \mathrm{~h})$. Lane 4: Supercoiled DNA of pBR322 incubated with hTopl from the clone resistant to $0.75 \mathrm{mg} / \mathrm{ml}$ Geneticin $(60 \mathrm{~h})$. Lane 5:

Supercoiled DNA of pBR322 incubated with hTopl from the clone resistant to $1.00 \mathrm{mg} / \mathrm{ml}$ Geneticin (48 h). Cropped images of gels/blots; full-length gels/blots can be presented on reasonable request. Control and marker were run on the same gels/blots.
(A)
(B)

\section{$\underline{1 \text { day }} \quad \underline{2 \text { day }} \underline{3 \text { day }}$}

\section{Quercetin}

$0 \mu \mathrm{g} / \mathrm{ml}$

$0.25 \mu \mathrm{g} / \mathrm{ml}$

$0.50 \mu \mathrm{g} / \mathrm{ml}$

$0.75 \mu \mathrm{g} / \mathrm{ml}$

$1.00 \mu \mathrm{g} / \mathrm{ml}$
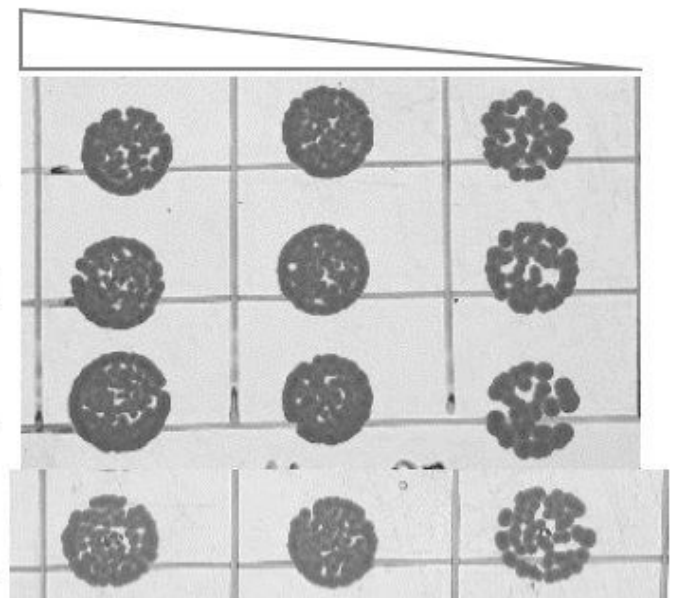

$\underline{\text { F1 }}$

$0.25 \mu \mathrm{g} / \mathrm{ml}$

$0.50 \mu \mathrm{g} / \mathrm{ml}$

$0.75 \mu \mathrm{g} / \mathrm{ml}$

$1.00 \mu \mathrm{g} / \mathrm{ml}$

\section{1 day 2 day $\underline{3 \text { day }}$}

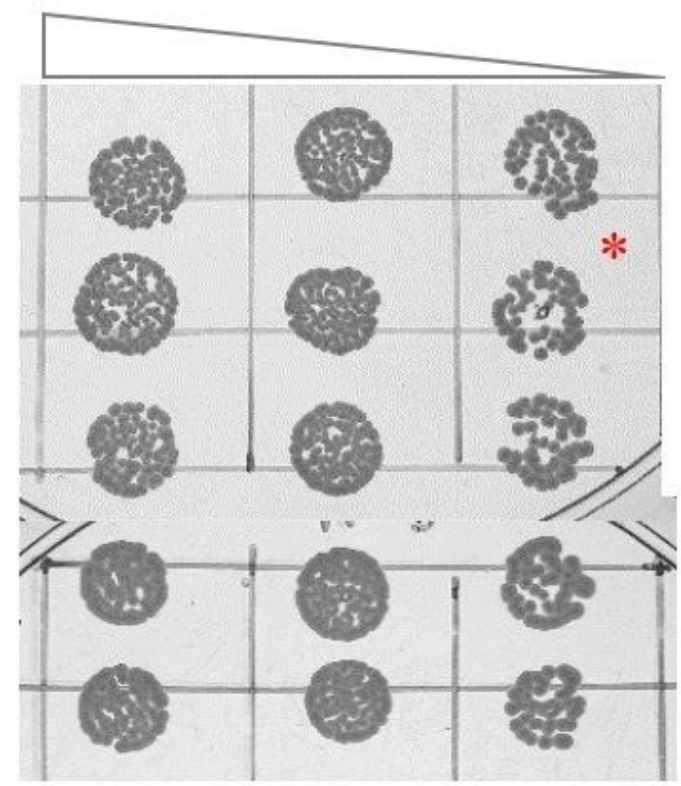

\section{Figure 7}

Yeast extract agar plates that contained (A) quercetin and (B) F1. The agar plates contained 0 (control), $0.25,0.50,0.75$, and $1.00 \mu \mathrm{g} / \mathrm{ml}$ quercetin or $\mathrm{F} 1$. The growth of the recombinant P. pastoris transformants on the plates were incubated for 1, 2, and 3 day. Each recombinant was spotted in triplicates on the agar plat prior 7.81×10-10 dilution. Cropped images of agar gel; full-length agar gels can be presented on reasonable request. Controls were derived from the same experiment, and the agar gels were processed in parallel. 

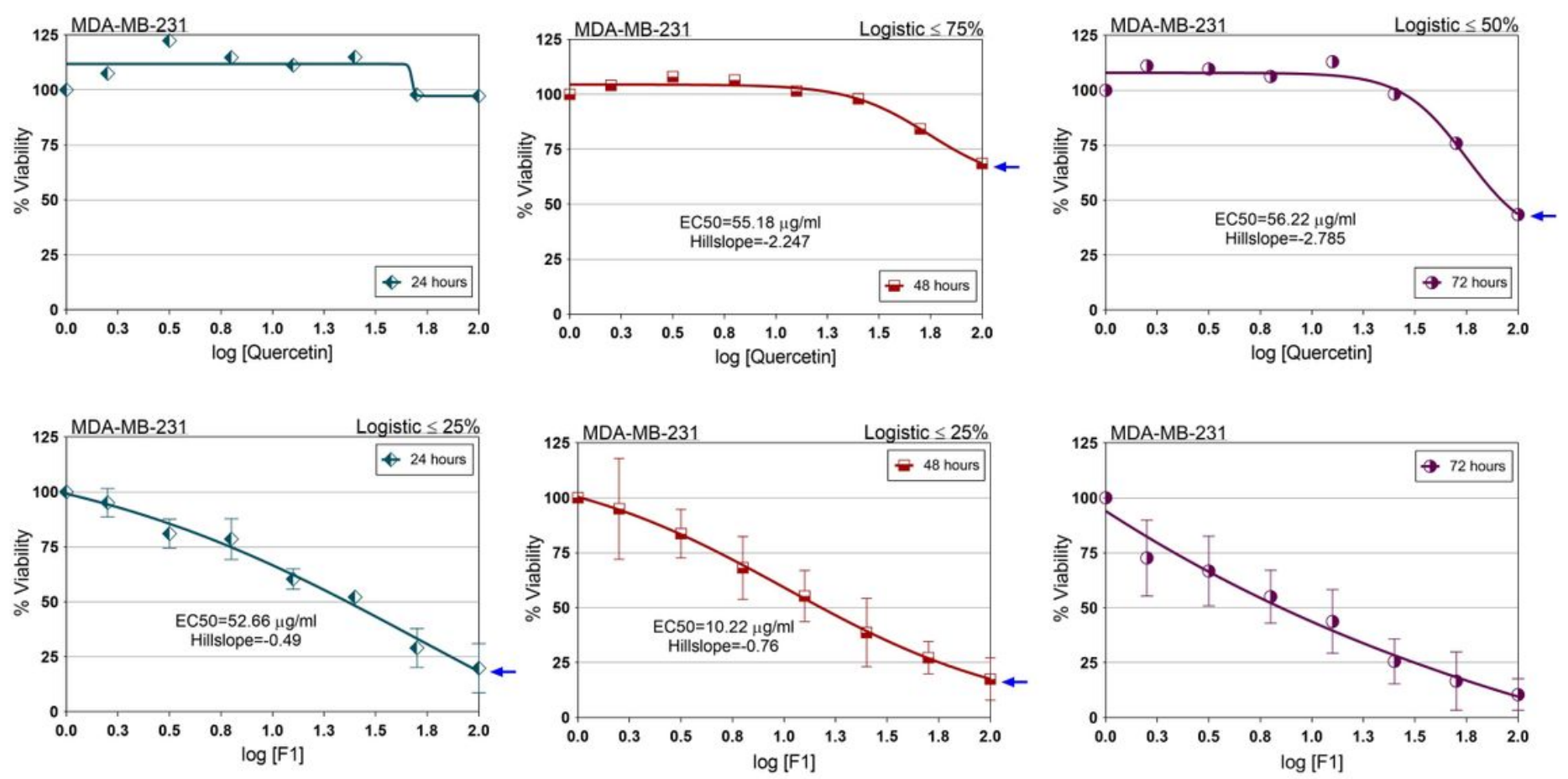

\section{Figure 8}

Dose-response curves of MDA-MB-231 following treatments with quercetin for (A) 24, (B) 48, and (C) $72 \mathrm{~h}$, and with $F 1$ for (D) 24, (E) 48, and (F) $72 \mathrm{~h}$. The maximal response (inhibition rate at the maximum dose concentration) identified hillslope value (slope at EC50 value) and an EC50 value of each test compound from the curve. The experiments were repeated several times to ensure the repeatability and reproducibility of the results. All values are expressed as the means \pm SD. $A * p<0.05$ was regarded as statistically significant. 

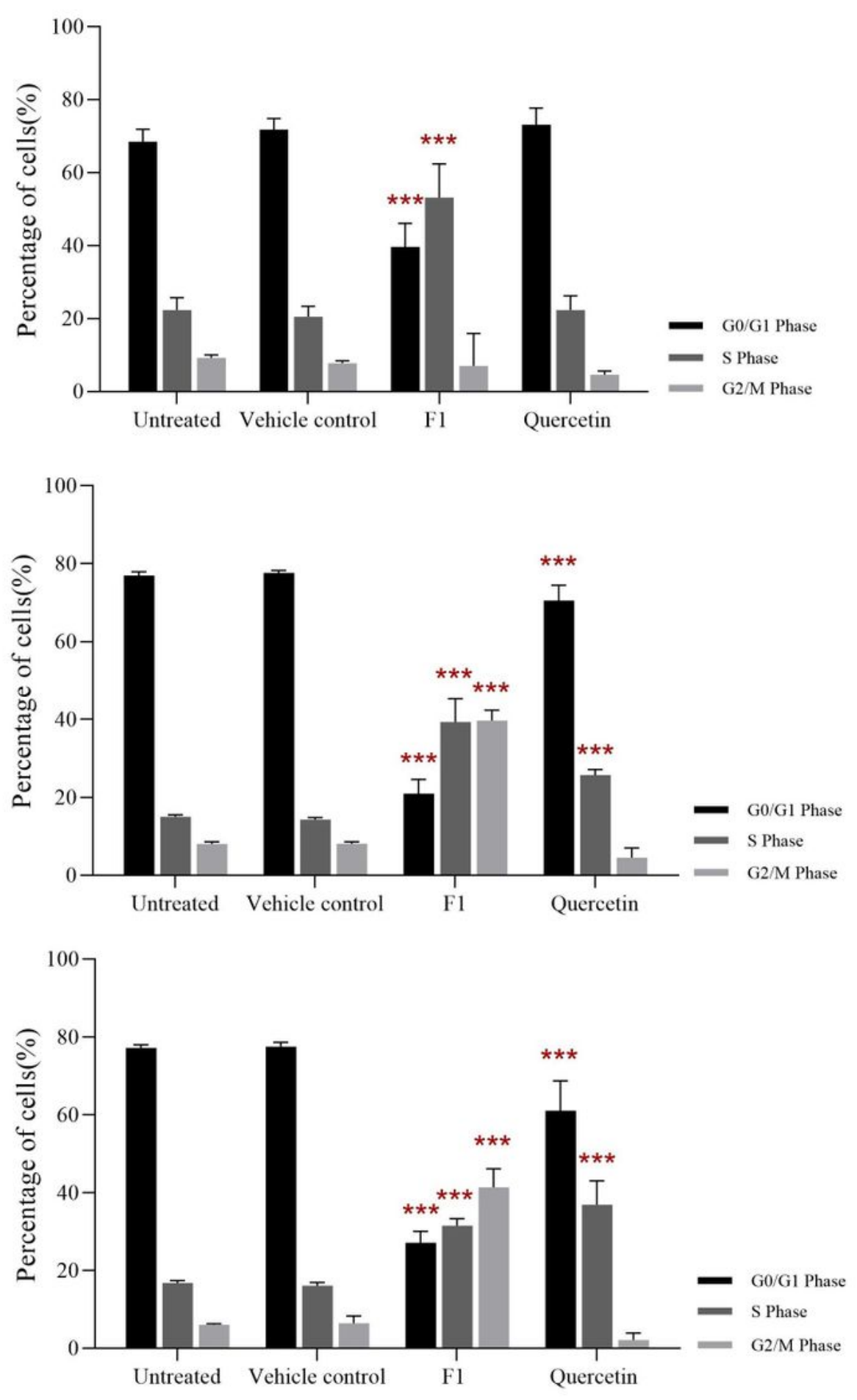

\section{Figure 9}

Cell cycle profile of quercetin $(60 \mu \mathrm{g} / \mathrm{ml})$ and F1 $(50 \mu \mathrm{g} / \mathrm{ml})$ in MDA-MB-231 after (A) 24, (B) 48, and (C) $72 \mathrm{~h}$ of treatment. Each data set represents the mean of 2 independent experiments with triplicate readings each. Significant differences were analysed vs untreated sample using one-way ANOVA and Dunnett's multiple comparisons test indicated as * $p<0.05$; $* \star p<0.01$; and ${ }^{* \star \star} p<0.001$. Untreated: nontreated cells and vehicle control: DMSO-treated cells. 

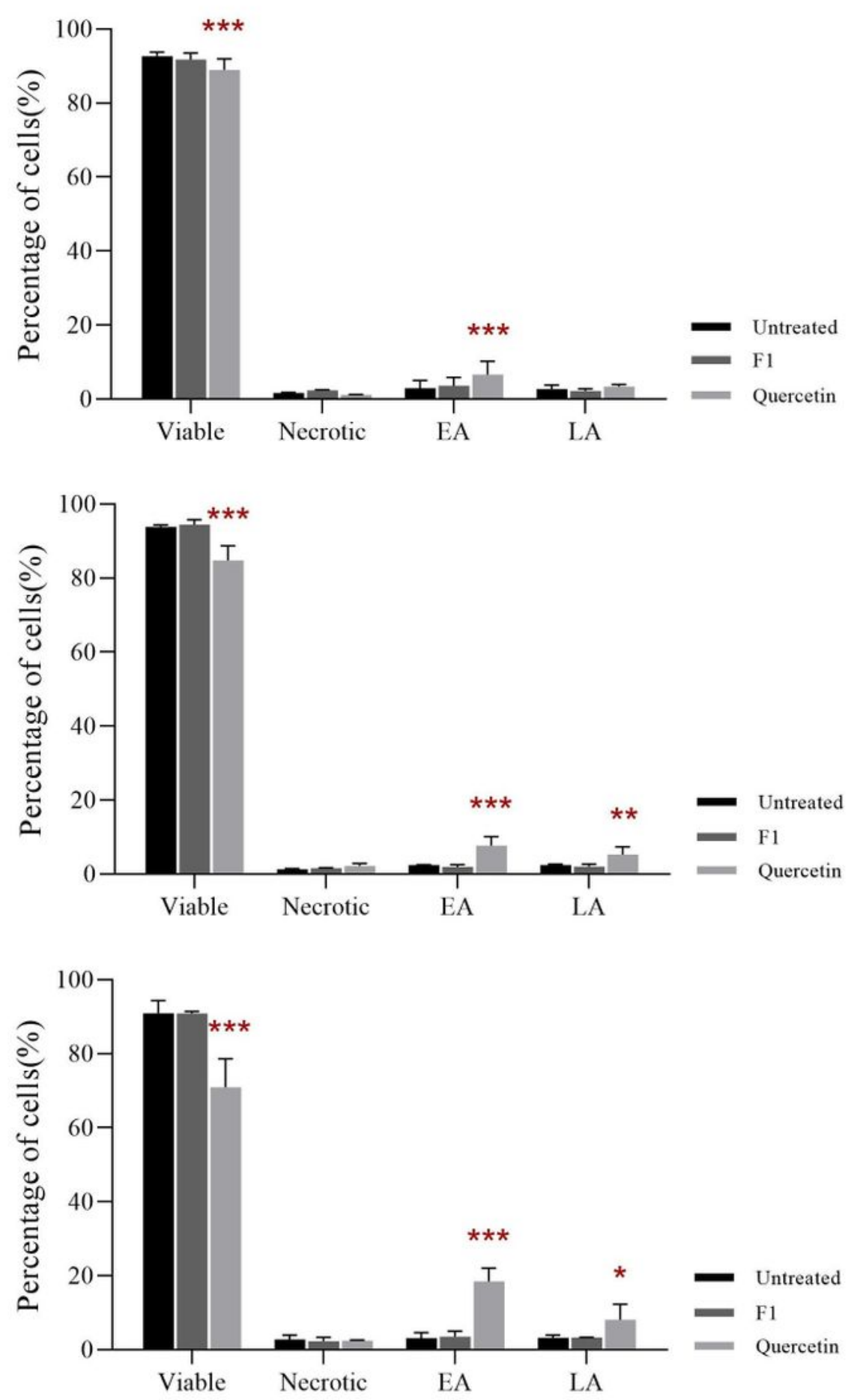

\section{Figure 10}

Apoptotic effect of quercetin $(60 \mathrm{mg} / \mathrm{ml})$ and $\mathrm{F} 1(50 \mathrm{mg} / \mathrm{ml})$ in MDA-MB-231 after (A) 24, (B) 48, and (C) $72 \mathrm{~h}$ of treatment. Each data set represents the mean of 2 independent experiments with triplicate readings each. One-way ANOVA and Dunnett's multiple comparisons test were used to interpret statistically significant differences between treated and untreated cells (control) as ${ }^{\star} p<0.05$; ${ }^{*} p<0.01$; $\star \star \star * p<0.001$. EA: early apoptosis, LA: late apoptosis. 

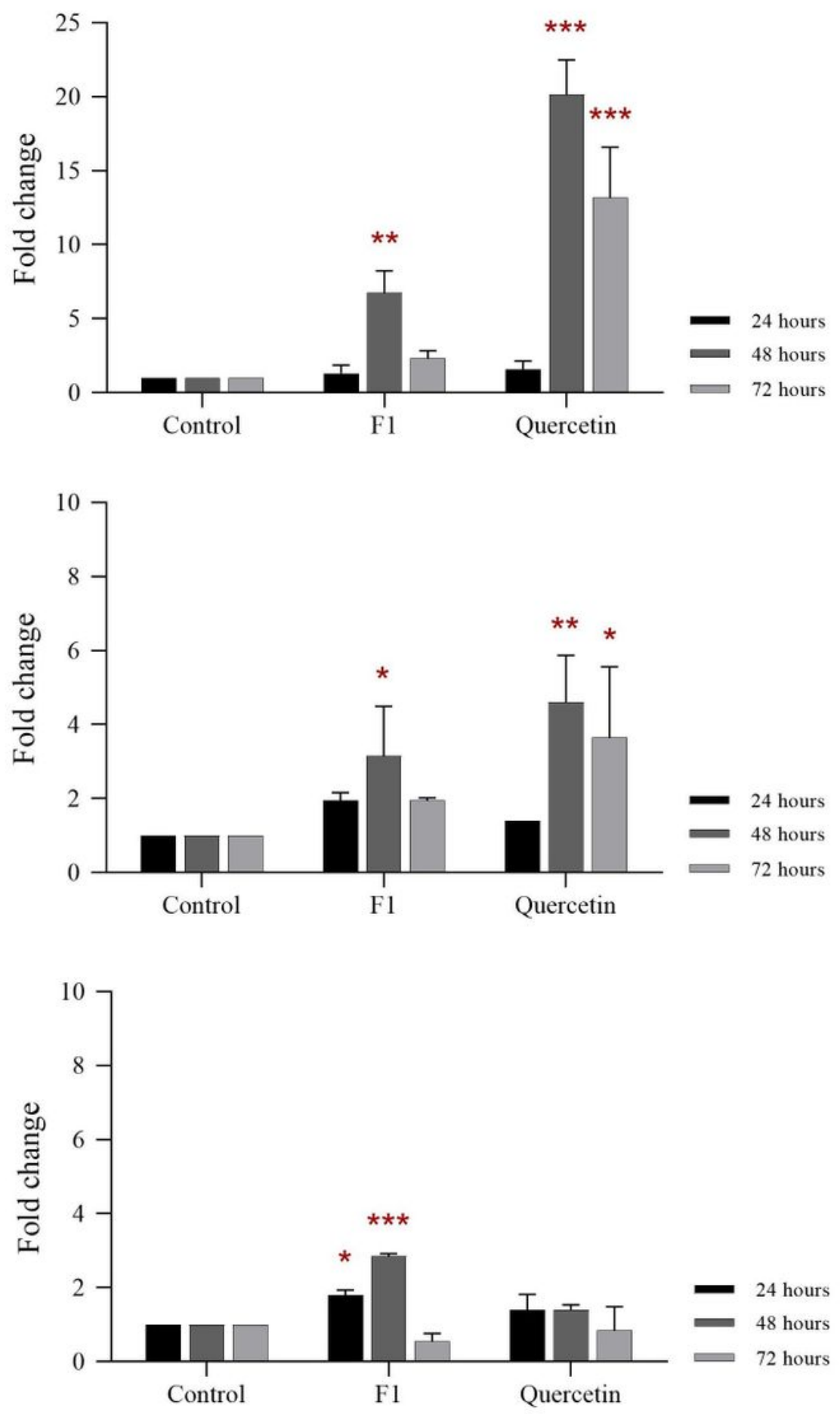

\section{Figure 11}

Effect of quercetin $(60 \mathrm{mg} / \mathrm{ml})$ and $\mathrm{F} 1(50 \mathrm{mg} / \mathrm{ml})$ on mRNA gene expression of (A) CYP1A1, (B) CYP1B1, and (C) CYP2S1 in MDA-MB-231. mRNA expression was normalised to the expression of GAPDH in each sample. The bar chart represents the mean $\pm S D$ of 2 independent experiments with significant differences indicated as $* p<0.05$; $* * p<0.01$; and ${ }^{* \star *} p<0.001$, compared to the controls. One-way ANOVA and Dunnett's multiple comparisons test were used for the statistical analysis. 